U. S. Department of the Interior

Geological Survey

Water Resources Division

Washington, D. C.

GROUND WATER

IN THE CUL-DE-SAC PLATI

HAIPI

George C. Taylor, Jr.

United States Geological Survey

and

Remy C. Lemoine

Service Cooperatif Inter-American

de la Production Agricole

Prepared under the auspices of

The Institute of Inter-American Affairs

1949

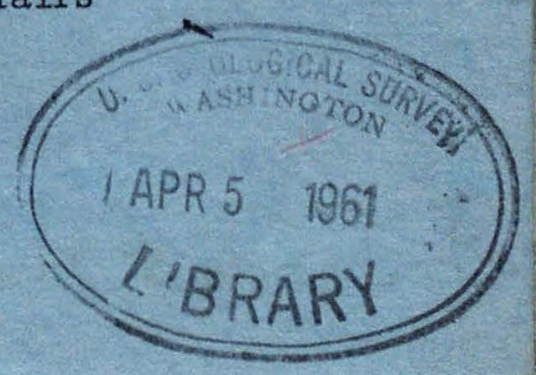


UNITED STATES DEPARTMENT OF THE INTERIOR

U. S. GEOLOGICAL SURVEY

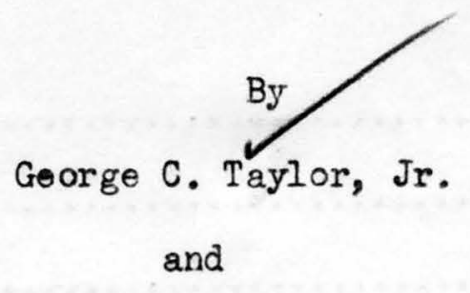

Remy C. Lemoine

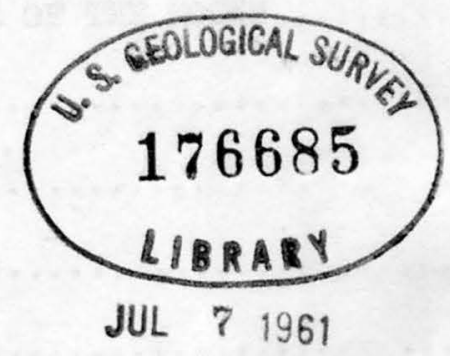




\title{
GROUND WATER IN THE CUL-DE-SAC PLAIN, HAITI
}

\author{
By \\ George C. Taylor, Jr., \\ U.S. Geological Survey \\ and \\ Rémy C. Lemoine \\ SCIPA
}

INTRODUCTION...................................

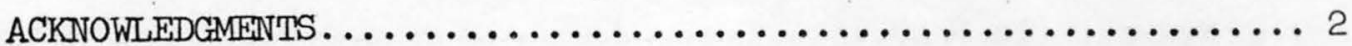

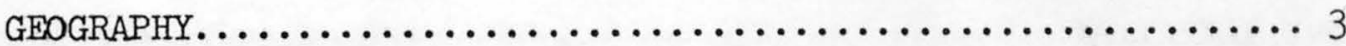

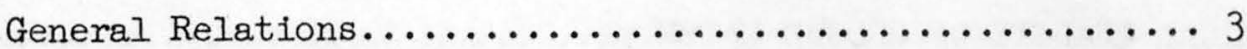

Surface Features and Drainage.................. 3

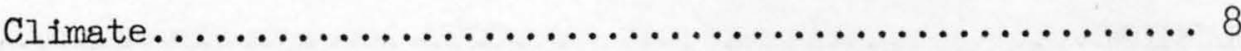

GEOLOGY AND WATER-BEARTNG PROPERTIES OF THE ROCKS.......... 14

General Features...............................

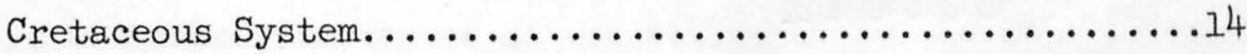

Tertiary System..........................

Eocene Series...........................

Oligocene Series..........................

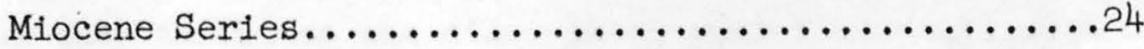

Pliocene ( $)$ Series.............................

Quaternary System...............................

Pleistocene Series........................

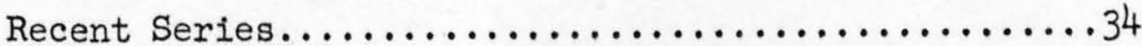




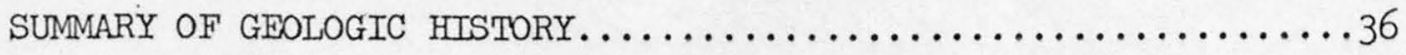

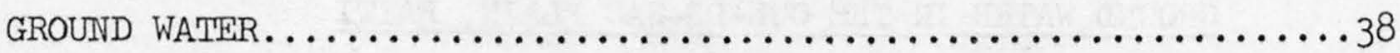

General Features................................

Northern System................................ 38

Southern System................................ 39

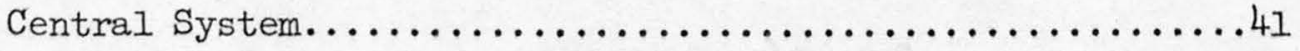

Recharge..............................

Ground-Water Circulation.....................43

Discharge.............................. 45

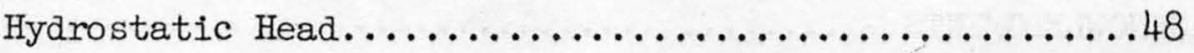

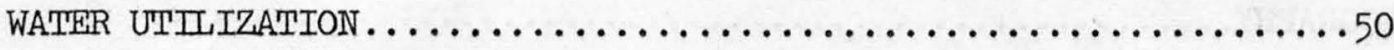

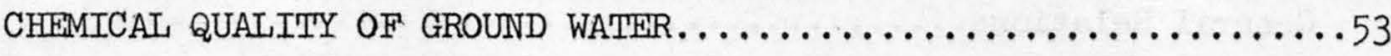

FUTURE DEVELOPMENT OF GROUND WATER.$\ldots \ldots \ldots \ldots \ldots \ldots \ldots \ldots \ldots \ldots$

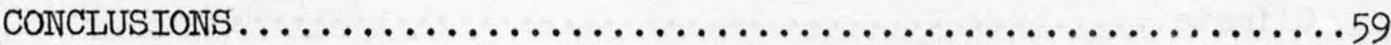


Translation from French of Remarks concerning the report entitled:

"Ground Water in the Cul-de-Sac Plain, Haiti"; by George C. Taylor Jr. and Rémy C. Lemoine.

The document in question is a remarkable study on the water resources of the Cul-de-Sac Plain and the actual possibilities of irrigation development, in this region. The authors have methodically considered the various aspects of the problem and therefore their conclusions have a great value. These form the basis of the present remarks.

The Cul-de-Sac Plain includes roughly an area of 30,000 hectares. Of these, 26,000 are in fact actually irrigated more or less with regularity. The authors of the above mentioned report estimate that the irrigated area could be increased by 4,000 hectares without detriment to the water supply of the existing irrigation facilities. In fact they insist, and justly, that although the amount of ground water withdrawn from wells by Hasco has markedly increased and that this company has been pumping considerable quantities of ground water during the past 25 years, the water levels in the aquifers have risen instead of lowering.

To obtain that increase the authors suggest two kinds of work:

1) Development of the existing springs with the object of increasing their yields by means of simple works at a reasonable cost.

a) For the following springs: (Plate I)

$\begin{array}{llll}\text { Source Papeau } & \text { (No. 2) } & \text { Sources Lagon } & \text { (No. 13) } \\ \text { Source Lathan } & \text { (No. 3) } & \text { Sources Greffin } & \text { (No. 31) } \\ \text { Source Balangnier } & \text { No. 6) } & \text { Sources Duthil } & \text { (No. 14) }\end{array}$

cleaning out aquatic vegetation from around the spring heads, trenching of spring heads to gather distended seepage and prevent infiltration 
losses, construction of small collecting tanks to regulate spring discharge.

b) For the following springs:

$\begin{array}{ll}\text { Sources Hatte Dumornay } & (\text { No. 10) } \\ \text { Source Diacroix } & \text { (No. 11) } \\ \text { Sources Fréres } & \text { (No. 29) } \\ \text { Source Métivier } & \text { (No. 38) }\end{array}$

Construction of short tunnels driven into the spring heads to enlarge and clear the natural outlets.

\section{2) Drilling of new wells:}

As a consequence of the disymmetry of the plain whose topographic surface as well as subsurface structure have their axis near the mountain range to the north, which dominates the plain, water tends to accumulate rather in the northern part of the plain.

It is not considered advisable to drill for production wells south of a line passing through Drouillard - Croix-des-Bouquets-Ganthier. To the north of this line, the block lying west of the Croix-des-Bouquets Morne á-Cabrits highway has been extensively drilled by Hasco. The authors believe nevertheless that additional wells could be drilled in this area If they are spaced far enough from existing wells. Personally, I belleve that we should be very cautious about this area and start by examining the results of new wells drilled in the area of which we are about to speak.

Few wells have been drilled in the block of land lying east of the Croix-des-Bouquets - Morne-á-Cabrits highway. The conditions appear also equally as favorable as those to the west of the highway and the best zone is west of the meridian of source Despuzeau. As in this region, due to the presence of a north-south divide near the meridian of La Serre, ground water 
is discharged in the Etang Saumâtre, there is little chance that such wells Influence the ground water body in the western part of the plain. The wells drilled in this region have serious chances of furmishing a good quantity of water. It would be wells of 50 to 200 meters with a lift between 10 and 25 meters. These wells should not be drilled in the proximity of Eaux Gaillées or the swamps of La Serre, for the lands there are very rich in salt.

In so far as the theoretical notions developed in the Memorandum which makes the object of this study are concermed, I permit myself to point out that I do not share the opinion of the authors of the memorandum, upon the areal distribution of the Miocene rocks in the southerm part of the Plain (only region that I have studied). In particular, as I have exposed in a memorandum being prepared for publication and consecrated to the geology of the southerm boundary of the Cul-de-Sac Plain, the fossils and the facies of the rocks lying on both sides of the Gros-Morne-Duval fault, otherwise somewhat displaced, are too different for them to be attributed the same age, due to their (topographic) proximity. The fact that the rocks lying south of the fault overlie without unconformity neither angular nor simple the middle Oligocene limestones of the Valley of the Grande Riviére du Cul-de-Sac, indicates that they englobe at least the upper Oligocene.

Concerming the recharge of the Miocene aquifers of the center of the plain, the authors attribute it almost entirely to infiltration in the lowlands. But they insist on the other hand, upon the development of impermeable layers in the superficial alluvium as well as in the Miocene strata. This poorly explains an infiltration, under these circumstances, especially with the Miocene being of marine origin, the impermeable horizons 
are much more continuous than in the superficial alluvium. One does not explain either how artesian wells may be had in the lower part of the plain which is almost horizontal. I think, for my part, that there is a non-negligible infiltration beginning with the Miocene outcrops of the boundaries of the plain. The authors object the intense folding of the Miocene in the southerm boundary and the absence of water in the wells drilled in this southerm zone. But the fact that the Cul-de-Sac Plain corresponds to a syncline whose axis of the folds plunge steeply, moreover the folds are not very close (about one fold every 1500 M.) must be kept in mind. At Morne Delmas the dip is not more than $10^{\circ}$. The attribution of the rocks lying south of the Gros Morne-Duval fault to a remoter age than the Miocene leads naturally more easily to the idea of a recharge of the Miocene aquifers of the center of the plain beginning with the bounder outcrops, the objections relative to the intense folding being dropped, at least partially.

Moreover, it must be said that that does not in any way modify the conclusions of the authors, on the subject of the work which it is desirable to execute, which conclusions I support entirely.

\author{
Jacques Butterlin \\ Professor "Agrege" of \\ Natural Sciences at the \\ French Institute of Haiti
}




\section{INIRODUCTION}

The Cul-de-Sac Plain is perhaps the most important agricultural area in Hait1 because of its nearness and accessibility to Port-au-Prince, the nation's capital, metropolis, and principal seaport. Most of the agricultural produce consumed in Port-au-Prince as well as a considerable part of that exported from Haiti is grown in the plain.

Because of variable and poorly distributed rainfall, high temperature, and high evaporation, semiarld climatic conditions prevall in the plain. Irrigation is, therefore, necessary for successful farming. There are no regulatory or storage facilities on the streams that enter the plain, but the mean and low-water stream flow and the discharge of springs are almost entirely appropriated for irrigation. Ground water has been utilized for irrigation to an increasing extent by the Haitian American Sugar Company, which has put down about 100 wells in the plain since 1919.

Outside the existing irrigated areas of the plain are large tracts of potentially irrigable land that are uncultivated and agriculturally unproductive for lack of water. The object of the present study was to determine the possibilities of bringing these lands into cultivation by irrigation from wells. This study was part of a larger program of the Food Supply Division, Institute of Inter-American Affairs, to increase the production of food in Hait1.

From September through November 1948 the senior author, a member of the U. S. Geological Survey, spent three months in the fleld in an investigation of the geology and ground-water resources of the Cul-de-Sac Plain. He was ably assisted by Mr. Rémy C. Lemoine, Haitian engineer-geologist, employed by the Food Supply Division. The field work included principally the geologic mapping 
of the plain and the adjacent mountain borders, a ground-water inventory of existing wells and springs, and a general evaluation of significant geologic and hydrologic features.

\section{ACKNOWLEEDGMENTSS}

The present ground-water investigation was initiated by $\mathrm{Mr}$. W. Alan Laflin, Chief of Party of the Food Supply Mission, Institute of Inter-American Affairs, in Haiti. The field work and preparation of the report were carrled out under Mr. Laflin's general direction. The writers are much indebted to him for help and encouragement during the course of their studies.

Rainfall and temperature data and spring and stream-flow records were furnished through courtesy of Mr. Felix Corneille, director of the Service des Eaux et Forêt and Mr. André Cauvin, chief of the Service d'Hydrologic et de Météorologie. Base maps and aerial photographs for field work were loaned by the Department des Travaux Publics, Mr. Georges Cauvin, administrator. Through the generosity of $\mathrm{Mr}$. Caleb Elliott, president, and $\mathrm{Mr}$. Fritz Dupuy, chief engineer, the records and logs of wells of the Haitian American Sugar Company were furnished for the purposes of the present study. Without these data an effective interpretation of the ground-water hydrology of the Cul-de-Sac Plain would not have been possible. Chemical analyses of water samples collected during the present study were made by Mr. Arnauld Haspil, chemist of the Section de Chimie, Départment de I'Agriculture. Mr. Haspil kindly made his past records of chemical analyses of waters from wells and springs available for the present study. The present report was reviewed by members of the U. S. Geological Survey. 


\section{GEOGRAPHY}

\section{General Relations}

Hispaniola is the second largest of the West Indian islands and is Iocated between Puerto Rico to the east and Cuba and Jamaica to the west. It lies between $17^{\circ} 39^{\prime}$ and $20^{\circ} 00^{\prime}$ north latitude and $68^{\circ} 20^{\prime}$ and $74^{\circ} 30^{\prime}$ west longl. tude. The Republic of Haiti occupies approximately the western third of the island and the Dominican Republic the eastern two-thirds.

The Cul-de-Sac Plain is part of a prominent structural and topographic trough that extends across the island of Hispaniola from Port-au-Prince Bay to Neiba Bay. That part of the trough located in the Dominican Republic is called the Enriquillo Basin. The Cul-de-Sac Plain is bordered on the north by the Montagnes du Trou d'Eau, and on the south by the Massif de la Selle. It is Iimited on the west by Port-au-Prince Bay and on the east by Etang Saumâtre, the largest inland lake of the Republic.

\section{Surface Features and Drainage}

The Cul-de-Sac Plain is approximately rectangular in outline, although its eastern end is somewhat wider than the western. The general trend of the axis of the plain is about west-northwest. Its length from Port-au-Prince Bay southeastward to Etang Saumatre is about 30 kilometers, and the average width between the bordering mountain ranges is approximately 16 kilometers. Most of the area of the plain is less than 60 meters above sea level. Its outline and principal surface features are shown in plate $I$.

The surface of the plain slopes generally northward almost to the base of the Montagnes du Trou d'Eau, For this reason its lowest axis is found along the northerm margin. In the eastern part of the plain is a broad, low 
north-south divide which diverts a part of the surface drainage eastward to Etang Saumatre and a larger part westward to the sea.

Near the midale of the lowest axis of the plain is a shallow depression called Eaux Gaillees, which is an extensive swampy tract containing several small fresh-water ponds. Formerly, the depression was occupled by a single shallow lake whose area fluctuated greatly with seasonal rainfall, and it is said to have overflowed occasionally after heavy rains into the Ravine Boucan Brou. However, the area flooded in the depression is now controlled artificially by a drain which carries excess water to the Etang Saumâtre.

At the eastern end of the plain is a much larger depression occupied by the Etang Saumâtre, a large brackish-water lake which has no surface outlet. The lake level is reported to fluctuate principally with cycles of wet and dry years. According to Tippenhauer $1 /$, the water surface of the lake in 1900 was, shown by instrumental levels run from Port-au-Prince, 20 meters above sea level. However, several random measurements made by the Service d'Irrigation between 1919 and 1927 indicate that the lake level was considerably lower during that period.

Elevation of the Water Surface of Etang Saumâtre near Mannevilie, in Meters Above sea Level ?]

\begin{tabular}{|c|c|c|c|c|c|}
\hline Month & Year & $\begin{array}{l}\text { Water } \\
\text { Surface }\end{array}$ & Month & Year & $\begin{array}{l}\text { Water } \\
\text { Surface }\end{array}$ \\
\hline & 1919 & $13 \cdot 5$ & December & 1926 & 12.6 \\
\hline July & 1924 & 13.2 & March & 1927 & 12.5 \\
\hline February & 1926 & 12.9 & July & 1927 & 12.6 \\
\hline May & 1926 & 12.8 & & & \\
\hline
\end{tabular}

I/ Tippenhauer, L. G., Beitrage zur Geologic Haitis, V: Petermanns Mitt., Band 47, p. 170, 1901 .

2) Les eaux de surface de la Republique d'Hait1, 1926-27: Bull. Hydrographique No. 5, Dept. des Travaux Publics, Service d'Irrigation, p. 86, Port-au-Prince, Haiti, 1927. 
In the spring of 1948 the lake level was 14.8 meters above sea level, according to instrumental levels run by the Inter-American Geodetic Survey, and in February 1949 it was 13.6 meters above sea level, according to measurements made by SCIPA engineers. These data and the observation of Tippenhauer demonstrate that the lake level has moved through a vertical range of at least 8 meters in the past 50 years. The lake now covers an area of about 180 square kilometers.

The northern half of the Cul-de-Sac Plain is smooth and nearly level almost to the base of the Montagnes du Trou d'Eau. The southern half of the plain has a pronounced northward slope. Moreover, its continuity is Intermupted in places by ridges and foothills along the base of the Massif de la Selle. At the southeast corner of the plain near Ganthier are low ridges that separate Etang Saumâtre from the Massif de la Selle. These rldges reach elevations of about 150 to 170 meters above sea level. About $4 \mathrm{kilometers} \mathrm{southeast} \mathrm{of} \mathrm{Croix-des} \mathrm{Bouquets} \mathrm{is} \mathrm{a} \mathrm{low} \mathrm{isolated} \mathrm{ridge} \mathrm{that}$ trends northwest and rises about 15 to 35 meters above the surrounding plain. An extensive area of foothills lies between Port-au-Prince and Pétionville and for a distance of 5 to 6 kilometers to the northeast of these cities. Near the base of the Massif de la Selle at Pétionville the footh1lls reach elevations of about 350 to 400 meters above sea level.

The principal streams of the Cul-de-Sac Plain are the Rivière Grise (also called the Grande Rivière du Cul-de-Sac) and the Rivière Blanche. They rise on the northern slope of the Massif de le Selle at elevations of about 1,300 to 1,800 meters above sea level. Both streams flow through deep gorges in their upper courses and enter the plain about 9 kilometers apart near the middle of the southern margin. The Rivière Grise flows 
northwest and west across the plain to enter the sea about 8 kilometers north of Port-au-Prince. The flow of the Riviere Blanche generally seeps away in the stream channel a short distance north of the southern margin of the plain. However, the flood flow of the stream may reach the depression of Eaux Gaillées. Numerous small ravines drain into the plain from the Montagnes du Trou d'Eau and the Massif de la Selle. The streams that follow these ravines are all intermittent except for short perennial stretches sustained by large springs.

In the lowland area of the plain are several small perennial streams fed principally by spring discharge. The most important of these are Rivière des Orangers, Riviere Despuzeau, and Ravine Boucan Brou. About 1932, the natural channel of Ravine Boucan Brou was rectified and deepened by the Départment des Travaux Publics. Since that time the effectiveness of the ravine as a drain has been increased by the construction of a ramified system of open tributary drains which extend east almost to the edge of the Eaux Gaillées depression.

The largest and most important of the streams of the Cul-de-Sac Plain is the Rivière Grise. Practically all of its flow originates in its mountain watershed, which includes an area of about 290 square kilometers. The discharge characteristics of the Rivière Grise during the period $1922-40$ are indicated below. The discharges were measured by the Service d'Irrigation at a point just upstream from the diversion dam of Bassin General. 
Riviere Grise Discharge Characteristics

During the Period 1922-40

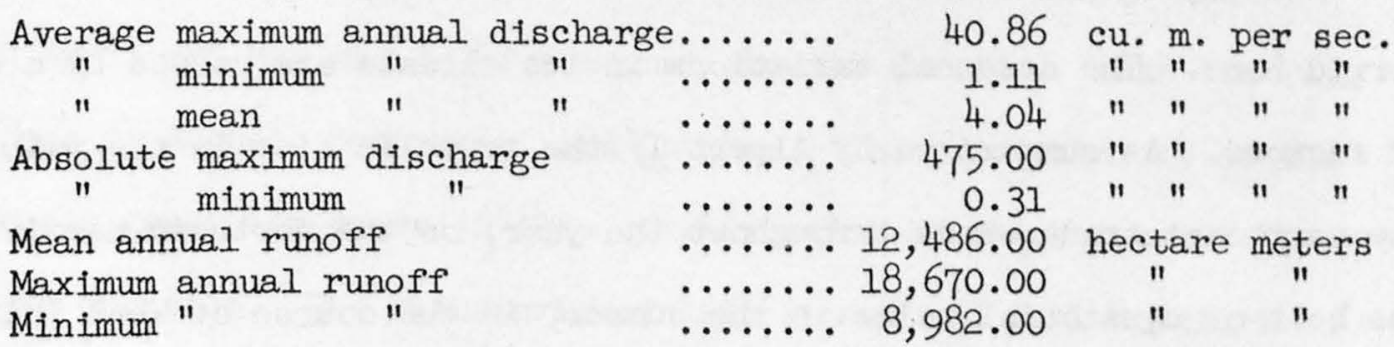

The Rivière Blanche is the second most important stream of the Cul-deSac Plain. Its mountain watershed covers 155 square kilometers. The discharge characteristics of the stream during the period $1922-40$ are given below. These data are based on measurements made by the Service d'Irrigation at a point a short distance upstream from the diversion dam at the mouth of the Blanche canyon.

\section{Rivière Blanche Discharge Characteristics} During the Period 1922-40

Average maximum annual discharge ${ }_{n}$ minimum $"$ "
mean

As suggested by the foregoing data, the flows of the Rivière Grise and Blanche may fluctuate through a wide range each year. Moreover, the periods of maximum and minimum discharge correspond closely to the progression of the ralny and dry seasons in the mountain watersheds. 


\section{$\underline{\text { Climate }}$}

The Republic of Haiti is situated in the northern part of the north Torrid Zone. The seasonal variations in its climate are caused by a number of factors. As summarized by Alpert $I /$ the republic lies in the path of the northeast trade winds throughout the year, on the northerm margin of the belt of equatorial rains in the summer, in the course of West Indian hurricanes and other tropical storms in the autumn, and at times near the southern margin of the Polar Front in the winter. Each climatic factor is dominant during the corresponding season of the year and makes itself felt in certain regions of the republic more than in others. These factors, together with the mountainous relief of the republic, are responsible for irregularities in the areal and seasonal distribution of rainfall, as well as in the temperature.

Although the bordering mountain ranges recelve moderate to abundant rainfall, the Cul-de-Sac Plain is one of the driest areas of the republic. As shown in table 1 , the mean annual rainfall over the lowland area of the plain ranges from about 750 to 1,100 milimeters. According to Alpert 2 / the rainfall on the bordering foothills is from about 1,000 to 1,250 millimeters. On the higher slopes of the Massif de la Selle the average annual rainfall ranges from about 1,850 to more than 2,500 millimeters, but even on the highest parts of the Montagnes du Trou d'Eau the annual rainfall is generally less than 1,500 millimeters.

The rainfall in the Cul-de-Sac Plain and for that matter in all of Hait1 is markedly seasonal. There are two well-defined wet seasons, one I/ Alpert, Leo., La répartition superficielle des pluies à travers la République d'Haiti: Revue Agricole d'Haiti, vol. 1, no. 3, pp. 185-186, April 1946. 2/ Alpert, Leo, op. cit. p. 187, 1946. 
in the spring and one in the fall. As shown by rainfall records in table 1 , the spring rainy season in the region of the Cul-de-Sac Plain generally occurs in April and May and is of somewhat shorter duration than the fall rainy season in August, September, and October. The precipitation of the spring season generally comes in slow, steady rains of several hours to 2 or 3 days duration. The rainstorms of late summer and fall result from the northward migration of the equatorial storm belt during this period. Most of the rain, especially in the drier areas, falls in local conventional storms of brief duration but high intensity. These storms are generally accompanied by considerable lightning and thunder and occasionally by hall. Hurricanes, which are so devasting to other parts of Haiti and to other West Indian islands, have never been recorded at Port-au-Prince or in the Cul-de-Sac Plain. Apparently the plain occupies a strongly protected position In the lee of bordering mountain ranges.

Although the annual rainfall received by the Cul-de-Sac Plain is equal to or greater than that of humid regions of the Temperate Zone, the climate of the plain is distinctly semiarid. This condition is attributed to the constant high temperatures and consequent high evaporation. Moreover, the soil moisture built up during the rainy seasons is soon depleted in the hot, dry seasons that follow.

The mean monthly temperatures of three typical stations in or near the Cul-de-Sac Plain are shown in table 2. The temperatures follow even curves corresponding to the regular progression of the seasons in the northern hemisphere. At Kenscoff and Damien, February is the coolest month, and September is the warmest month. However, at Port-au-Prince the coolest month is January, and the warmest month is July. One notable feature is the small 
range of the mean monthly temperatures during the year. Between the warmest and coolest months the difference is only $6.0^{\circ} \mathrm{C}$. at Kenscoff and just $3 \cdot 3^{\circ} \mathrm{C}$. at Port-au-Prince. The smaller difference at Port-au-Prince may be due to Its nearness to the sea, with the consequent equalizing influence of land and sea breezes. Another marked feature is the lowering of temperature with altitude. The mean monthly temperature for Kenscoff, altitude 1,420 meters, is consistently 8.3 to 11.1 degrees lower than that for Damiens, altitude 23 meters. It has been suggested I/ that in and near the Cul-deSac Plain a lowering of about $1^{\circ} \mathrm{C}$. in the mean annual temperature takes place for each increase of 150 meters in altitude above sea level.

The evaporation from a free-water surface at Port-au-Prince has been measured by means of a "Piche" evaporometer located on the roof of the Travaux Publics building. The mean relative monthly and yearly evaporation, in millimeters, as based on about 15 years of observation is as follows:

\begin{tabular}{llllll}
\hline January & 151 & May & 180 & Sept. & 178 \\
February & 163 & June & 197 & Oct. & 163 \\
March & 207 & July & 195 & Nov. & 138 \\
April & 178 & Aug. & 215 & Dec. & 150 \\
\multicolumn{5}{c}{ Year:-2,115 } \\
\hline
\end{tabular}

The foregoing data probably portray, in a general way, the evaporation characterlstics of the Cul-de-Sac Plain. The principal factors affecting evaporation appear to be temperature, seasonal rains, and wind movement. I/ Woodring, Wendell P., Brown, John S., Burbank, Wilbur S., Geology of the Republic of Haiti: Republic of Haiti, Dept. of Public Works, Geological Survey of Hait1, p. 40, Port-au-Prince, 1924. 
Mean Monthly and Annual Rainfall, in Millimeters, of Stations in or Near the Cul-de-Sac Plain, Haiti From Data Furnished by Service Des Eaux et Forêts

\begin{tabular}{|c|c|c|c|c|c|c|c|c|c|c|c|c|c|c|c|}
\hline Station & $\begin{array}{l}\text { Altitude } \\
\text { (meters) }\end{array}$ & $\begin{array}{l}\text { Years } \\
\text { of } \\
\text { record }\end{array}$ & Jan. & Feb. & Mar. & April & May & June & JuIy & Aug. & Sept. & Oct. & Nov. & Dec. & Annual \\
\hline $\begin{array}{l}\text { Port- } \\
\text { au-Prince }\end{array}$ & 37 & $\pi$ & 33.8 & $57 \cdot 7$ & 85.9 & 158.3 & 232.4 & 100.6 & 73.4 & 144.1 & 174.2 & 169.2 & 86.8 & 32.4 & 1348.8 \\
\hline Ganthier & 177 & 43 & 13.6 & 21.5 & 38.4 & 121.7 & 142.6 & $47 \cdot 7$ & 33.7 & 67.9 & 109.5 & 122.1 & 59.0 & 20.0 & 797.7 \\
\hline $\begin{array}{l}\text { Pétion- } \\
\text { ville }\end{array}$ & 400 & 49 & 26.1 & 48.4 & 90.0 & 186.9 & 251.2 & 130.4 & 90.9 & 139.5 & 191.8 & 178.1 & $79 \cdot 3$ & 27.6 & 1440.2 \\
\hline Kenscoff & 1,420 & 15 & 19.4 & 42.2 & 53.0 & 249.9 & 384.5 & 272.9 & 142.7 & 228.5 & 271.9 & 273.1 & 105.6 & 50.0 & 2093.7 \\
\hline Thomazeau & 35 & $4 I$ & 9.2 & 20.2 & 37.7 & 86.8 & 145.8 & 58.9 & 58.9 & 91.9 & 119.0 & 127.9 & 56.6 & 11.9 & 824.8 \\
\hline Damien & 23 & 22 & 35.2 & 41.4 & 68.9 & 105.5 & 191.9 & 81.2 & 66.9 & 126.7 & 126.0 & 139.5 & 79.7 & 22.1 & 1085.0 \\
\hline $\begin{array}{l}\text { Croix-des- } \\
\text { Bouquets }\end{array}$ & 57 & 25 & 18.6 & 33.9 & 53.0 & 107.9 & 142.6 & 67.4 & 63.8 & 124.0 & 123.6 & 131.7 & 50.1 & 14.7 & 931.3 \\
\hline
\end{tabular}




\section{TABLE 2}

Mean Monthly and Annual Temperatures, in Degrees Centigrade, of Stations in or near the Cul-de-Sac Plain From Data Furnished by Service des Eaux et Forêts

$$
\text { Port-au-Prince }
$$

Damfens

\section{Years of}

Record

51

15

20

January

24.7

15.4

24.2

February

25.0

13.0

24.1

March

25.6

15.8

25.1

April

26.2

16.6

26.0

May

26.6

17.6

26.6

June

27.5

18.2

27.1

July

August

28.0

18.7

27.8

$27 \cdot 7$

18.4

27.4

September

27.1

19.0

28.2

October

26.5

18.2

26.8

November

December

Annual
25.8

24.9

26.3
15.2

17.0
17.6
25.9

24.4

. 
Evaporation is least during November, December, and January, when the temperature and wind movement are relatively low. It increases in February and March with the advance of the dry season and with a gradual increase in temperature and wind movement. In April and May the amount of evaporation is checked somewhat by the spring rainy season, although there is considerable wind movement in this period. With the coming of the summer dry season and high temperatures, the evaporation is greatest, in June, July, and August. It appears to be generally highest in August, in spite of the beginning of the fail rainy season in the latter part of that month. The rate of evaporation in September and October is mitigated by the fall rainy season and by relatively low wind movement.

As a consequence of the climatic and soil conditions, the natural vegetation of the plain has a distinct xerophytic aspect. Spiny vegetation abounds, and members of the cactus family are numerous. Varieties of opuntia and columnar cereus cactus are abundant. Where soil and moisture conditions are good, dense thickets of bayahonde occur. This is a scrubby leguminous tree resembling the mesquite of southwestern United States. The wood in the form of charcoal is widely used for fuel. On the foothill and mountain slopes adjacent to the plain several kinds of agaves, yucca, and acacia occur. 


\section{GEOLOGY AND WATTER-BEARING PROPERTIES OF THE ROCKS}

\section{General Features}

In the Cul-de-Sac Plain and the adjacent mountain ranges rocks of the Tertiary and Quaternary systems rest on a basement of Cretaceous volcanic rocks. The general sequence and water-bearing properties of the rocks of the Cul-de-Sac region are summarized in table 3. The oldest rocks in the region are extrusive lavas and phroclastics of probable Upper Cretaceous age. Resting unconformably on these is a thick sequence of marine and littoral, calcareous and clastic sedimentary rocks belonging to the Eocene, Miocene, and Pliocene (?) series of the Tertiary system. Locally volcanic rocks of probable Oligocene age also occur. Overlying the Tertiary rocks are semiconsolidated and unconsolidated alluvial and marine deposits of the Pleistocene and Recent series of the Quaternary system.

\section{Cretaceous System}

Cretaceous rocks were not recognized in the area covered by plate I. However, to the south of the map area rocks of probable late Cretaceous age crop out extensively in the headwaters of the Rivière Grise and east-southeast of Furcy in the Massif de la Selle. According to Woodring and Brown I/ the area of outcrop may be from 500 to 600 square kilometers in extent. The rocks are principally basalts with some thin beds of impure tuffaceous limestone and tuff. They probably form most of the basement on which the Tertiary sediments were deposited in the Cul-de-Sac region. The water-bearing properties of these rocks were not observed during the present study, but it is probable that they would yield only meager quantities of water to wells and springs.

1/ Woodring, Wendell P., Brown, John S., Burbank, Wilbur S ., Geology of the Republic of Haiti: Republic of Haiti, Dept. of Public Works, Geological Survey of Haiti, p. 320, Port-au-Prince, 1924. 


\section{Tertiary System}

\section{Eocene Series}

Limestones of upper Eocene age crop out extensively in the Montagnes du Trou d'Eau and in the Massif de la Selle, but were not distinguished in the map area. According to Woodring and Brown I/ upper Eocene rocks are exposed over a large region in the west-central part of the Montagnes du Trou d'Eau. The rocks are generally dense, massive gray and white limestones, but locally some thin-bedded. limestones occur. The foraminifera Numulites sp., Orthophragmina crassa Cushman, Lepidocyclina subraulinti Cushman, and Dictyoconus puilboreauensis nannoides Woodring, of probable upper Eocene age, were collected by Woodring 2 / from limestone float on the north slope of Morne Terre Rouge. Upper Eocene limestones are widely distributed in the interior of the Massif de la Selle where they rest uncomformably on an irregular erosion surface cut in folded Upper Cretaceous volcanic rocks. Where this contact is exposed the basal part of the upper Eocene may contain some shale, sandstone, conglomerate, and sandy limestone. However, the upper Eocene rocks are generally either (I) dense, thin-bedded white limestones characterized by nodules or bands of chert parallel to the bedding, or (2) massive gray limestones that form solution breccias. On the crest of Morne Hôpital, Woodring and Brown $3 /$ collected the foraminifera Gypsina sp. and Operculina floridensis (Heilprin) from limestones considered to be near the middle of the upper Eocene section. The exposed thickness of the upper Eocene limestone in the Kenscoff-Furcy area is at least 500 meters 4 /.

The upper Eocene limestones of the Montagnes du Trou d'Eau and the Massif de la Selle are folded in great compound anticlines and synclines that generally trend west-northwest. Folds of small magnitude are commonly 1/ Woodring, Wendell P., Brown John S., Burbank, Wilbur S., op. cit, p. 128 2) Idem, p. 144 


\section{TABLE 3}

Generalized Columnar Section Showing the Sequence and Water-Bearing Properties of the Rocks of the Cul-de-Sac Plain and of the Adjacent Areas

\begin{tabular}{|c|c|c|c|}
\hline \multicolumn{2}{|l|}{ Age } & $\begin{array}{c}\text { Lithologic Character and Areal } \\
\text { Distribution }\end{array}$ & Water-Bearing Properties \\
\hline $\begin{array}{l}\Rightarrow 1 \\
\text { cor }\end{array}$ & 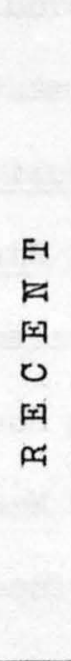 & $\begin{array}{l}\text { Unconsolidated stream-laid clay, } \\
\text { silt, sand, and gravel deposited } \\
\text { in irregular lenses and stringers. } \\
\text { Forms the uppermost part of the } \\
\text { alluvial fill as well as the al- } \\
\text { luvial fans bordering the Cul- } \\
\text { de-Sac Plain. }\end{array}$ & $\begin{array}{l}\text { The clays, silts, and fine sands } \\
\text { are essentially impervious and } \\
\text { nonproductive. The well-sorted } \\
\text { coarse-textured sands and gravels } \\
\text { yield moderate to abundant sup- } \\
\text { plies of good water to springs } \\
\text { and to wells at depths ranging } \\
\text { from a few meters to } 60 \text { meters } \\
\text { below the surface of the plain. } \\
\text { Within } 4 \text { to } 6 \text { kilometers of the } \\
\text { shore of Port-au-Prince Bay the } \\
\text { near-surface aquifers in the } \\
\text { Recent may contain water of } \\
\text { inferior chemical quality. }\end{array}$ \\
\hline 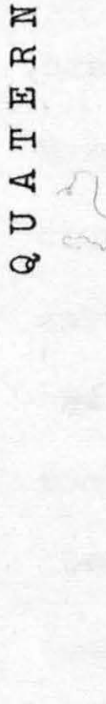 & 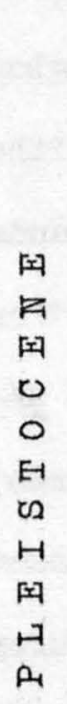 & $\begin{array}{l}\text { Semiconsolidated stream-laid } \\
\text { gravels and sand. Commonly } \\
\text { capped by caliche and cemented } \\
\text { with a limy matrix. Locally } \\
\text { grades into marine marls and } \\
\text { clays. Form an irregular dis- } \\
\text { sected blanket overlying } \\
\text { Miocene and Oligocene rocks } \\
\text { of most of the foothill areas } \\
\text { of the Cul-de-Sac Plain and } \\
\text { occur in dissected alluvial } \\
\text { fans on the borders of the } \\
\text { plain. Also underlie the } \\
\text { Recent in the lowland areas. }\end{array}$ & $\begin{array}{l}\text { In the foothill areas and dis- } \\
\text { sected alluvial fans the Pleis- } \\
\text { tocene is generally above the } \\
\text { regional zone of saturation. } \\
\text { Locally in these areas it yields } \\
\text { meager supplies of water to spring } \\
\text { and to wells at depths of general- } \\
\text { ly less than } 20 \text { meters. } \\
\text { Beneath the Recent alluvium of the } \\
\text { plain the Pleistocene may yield } \\
\text { moderate water supplies to wells } \\
\text { at depths of } 20 \text { to } 70 \text { meters below } \\
\text { the surface. }\end{array}$ \\
\hline
\end{tabular}




\begin{tabular}{|c|c|c|c|}
\hline & 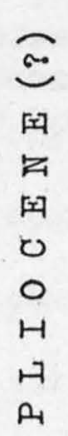 & $\begin{array}{l}\text { Soft white reef rock, corallif- } \\
\text { erous and molluscan limestone. } \\
\text { In places contains sand, gravel, } \\
\text { and coquina. } \\
\text { Underlies the foothills north } \\
\text { and east of Ganthier and south- } \\
\text { west of Etang Saumâtre. Also } \\
\text { occurs in limited areas to the } \\
\text { northwest of Eaux Gaillées. }\end{array}$ & $\begin{array}{l}\text { Generally above the reglonal } \\
\text { water table. Cavernous facies, } \\
\text { gravel, and coquina beds may } \\
\text { yield moderate supplies of water } \\
\text { to wells if present in the zone } \\
\text { of saturation. }\end{array}$ \\
\hline 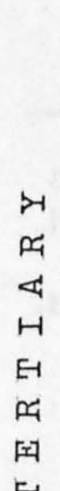 & $\begin{array}{l}\text { 国 } \\
\text { Z } \\
\text { 囯 } \\
0 \\
0 \\
0 \\
H \\
\sum\end{array}$ & $\begin{array}{l}\text { Semiconsolidated claystone, } \\
\text { siltstone, sandstone, and con- } \\
\text { glomerate interbedded with soft } \\
\text { marl and limestone. } \\
\text { Underlies dissected Pleistocene } \\
\text { gravels in foothills on the south } \\
\text { side of the Cul-de-Sac Plain, and } \\
\text { unconsolidated Recent and Pleisto- } \\
\text { cene deposits in the lowlands of } \\
\text { the plain. }\end{array}$ & $\begin{array}{l}\text { In the foothill areas the Miocene } \\
\text { rocks yield only meager quanti- } \\
\text { ties of water generally of poor } \\
\text { quality. Beneath the lowland } \\
\text { areas of the plain wells obtain } \\
\text { moderate to abundant water from } \\
\text { the sandstones, conglomerates, } \\
\text { and limestones at depths of about } \\
70 \text { to } 165 \text { meters. }\end{array}$ \\
\hline & 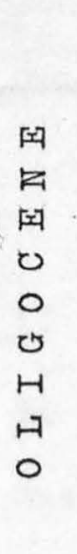 & $\begin{array}{l}\text { Hard gray, white, and buff-colored } \\
\text { limestone in thick massive beds on } \\
\text { the south slope of the Montagnes } \\
\text { du Trou d'Eau. Locally to east of } \\
\text { Thomazeau and north of Etang Sau- } \\
\text { mâtre contains intercalated nephe- } \\
\text { line basalt. On the north slope } \\
\text { of the Massif de la Selle is hard } \\
\text { gray and white chert-free limestone } \\
\text { in thin-bedded and massively bedded } \\
\text { facies. In the upper part contains } \\
\text { sandy and clayey limestones, clay- } \\
\text { stones, siltstones, and sandstones. }\end{array}$ & $\begin{array}{l}\text { The cavermous zones and the bed- } \\
\text { ding and joint planes of the lime- } \\
\text { stones are moderately to highly } \\
\text { pervious. Numerous springs of } \\
\text { moderate to large magnitude issue } \\
\text { from these zones in ravines along } \\
\text { the northerm and southern borders } \\
\text { of the plain. Probably lies too } \\
\text { deep beneath the lowland area of } \\
\text { the plain to be within the economic } \\
\text { limit of drilling. }\end{array}$ \\
\hline
\end{tabular}


TABLE 3

(Continued)

\begin{tabular}{|c|c|c|c|}
\hline Age & & $\begin{array}{c}\text { Lithologic Character and Areal } \\
\text { Distribution }\end{array}$ & Water-Bearing Properties \\
\hline 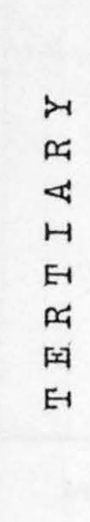 & 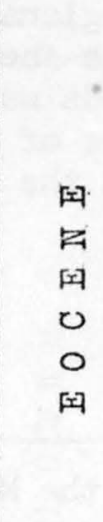 & $\begin{array}{l}\text { Hard white limestone, generally } \\
\text { thin-bedded, with chert in bands } \\
\text { and nodules parallel to bedding } \\
\text { planes. } \\
\text { Occasional thick massive beds } \\
\text { occur. These rocks are widely } \\
\text { distributed in the interior of } \\
\text { the Massif de la Selle and to } \\
\text { less extent in the Montagnes } \\
\text { du Trou d'Eau. They were not } \\
\text { recognized in the map area of } \\
\text { plate I. }\end{array}$ & $\begin{array}{l}\text { The water-bearing character- } \\
\text { istics of these rocks are prob- } \\
\text { ably similar to those of the } \\
\text { Oligocene rocks. }\end{array}$ \\
\hline $\begin{array}{l}0 \\
D \\
0 \\
\text { A } \\
0 \\
4 \\
\text { E1 } \\
\text { 囯 } \\
04 \\
0\end{array}$ & 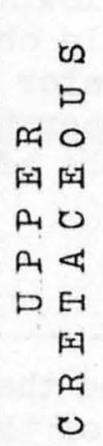 & $\begin{array}{l}\text { Basalt and andesite with some } \\
\text { beds of tuff, calcareous tuff, } \\
\text { and shaly limestone. } \\
\text { Outcrops extensively in the } \\
\text { headwater areas of the Riviére } \\
\text { Grise in the Massif de la Selle. } \\
\text { These rocks were not recognized } \\
\text { in the map area of plate I. }\end{array}$ & $\begin{array}{l}\text { Water-bearing characteristics } \\
\text { not observed. Probably would } \\
\text { yield only meager quantities } \\
\text { of water to wells and springs. }\end{array}$ \\
\hline
\end{tabular}


present on the limbs of the larger structures. In places where the folding has been most intense, crumpling of the beds has occurred. Locally overturned folds passing into thrust faults are developed in the upper Eocene rocks.

In the Massif de la Selle and the Montagnes du. Trou d'Eau are many springs of small to large magnitude that issue from the upper Eocene limestones. Most of these springs rise from joints and bedding planes or from channels formed by solution of the limestone. Such springs are common in the headwater tributaries of the Rivières Grise and Blanche and probably supply most of the low-water discharge of these streams.

\section{Oligocene Series}

Sedimentary rocks that are here considered to be of Oligocene age form the surface rock of most of the northerm border of the Massif de la Selle and the southern border of the Montagnes du Trou d'Eau. The areal extent of Oligocene rocks around the borders of the Cul-de-Sac plain is shown in plate I. The contact between the Eocene and Oligocene in the Cul-de-Sac region has not yet been clearly established on faunal evidence, and hence some areas mapped as Oligocene in plate I may be Eocene.

The lithology of the basal Oligocene rocks is very similar to that of the upper Eocene. For this reason rocks of the two units can scarcely be distinguished except by fossil evidence. On the north slope of the Massif de la Selle are rocks mapped as Eocene by Woodring, Brown, and Burbank I/ in 1921. However, at that time insufficient fossil evidence was avaliable to prove definitely the presence of Oligocene rocks, and it was recognized $2 /$ that the Oligocene might be present in areas described 1/ Woodring, Wendell P., Brown, John S., Burbank, Wilbur S., op. c1t, pl. I. 2) Idem, p. 145 
as Eocene. Later geologic and paleontologic work by geologists of the Atlantic Refining Company has shown that a considerable thickness of Oligocene rocks is present on the north slope of these mountains $1 /$. This work was done in connection with oil exploration in the Cul-de-Sac Plain during 1940-47.

On the south slope of the Montagnes du Trou d'Eau the Oligocene is chiefly massive white, and buff-colored limestone. The rock is commonly gray on weathered surfaces and pitted by solution. Locally solution breccias occur. The bedding of the rock is generally indistinct, and the rock is commonly broken into blocky masses by jointing. Limestones in the western part of the south slope of this range are considered to be of middle Oligocene age 2/. In the easterm part of the south slope the limestones are of upper Oligocene age $3 /$ and may be several hundred meters thick. To the northeast of Thomazeau upper Oligocene limestones rest on nepheline basalt containing abundant small phenocrysts of olivine. This basalt forms the surface rock in a small area east of Thomazeau (PI. I) and overlies limestone and limestone conglomerate. The upper Oligocene foram Sorites americana (Cushman) was collected 4 / from limestone underlying the basalt at a point 50 meters west of Sources Manneville.

The Oligocene rocks on the north slope of the Massif de la Selle are exposed in the canyons of the Rivières Grise and Blanche and on the north slope of Morne Hôpital, a high ridge just south of Port-au-Prince. In the canyon of the Rivière Grise near the diversion dam the midale and lower parts of the Oligocene section exposed are chiefly pure hard white and gray limestone in thin, even beds 5 to 20 centimeters thick. Occasionally thick 1/ Lemoine, Remy C., personal communication. 2/ Woodring, Wendell P., Brown, John S Burbank, Wilbur S., op. cit. p. 148. 3/ Idem, p. 153. 4/ Idem, p. 156 . 
massive beds of white and gray limestone are present. Chert layers and nodules, which are characteristically interbedded in the underlying upper Eocene limestones, are not abundant in the OlIgocene limestones. In the canyon of the Rivière Blanche near the diversion dam, the midale and lower parts of the Oligocene section are similar to those exposed in the Rivière Grise. However, massively bedded limestones are more common in the section. On the north slope of Morne Hôpital the thin-bedded and massively bedded facies of the Oligocene occur in about equal proportions.

Clastic sediments, which are rarely present in the middle and lower parts of the Oligocene section, are relatively abundant in the upper part of the section on the north slope of the Massif de la Selle. Near the diversion dam on the Rivière Grise and in the Ravines Dechapet and Mapou the upper part of the Oligocene section is made up of interbedded thin, platy argillaceous limestones, claystones, siltstones, and occasional sandstones and conglomerates. These rocks appear to grade downward into the limestones of the middle part of the section without pronounced unconformity. In a small ravine about $1-1 / 2$ kilometer east of Pétionville are thinbedded gray clayey and sandy limestones, claystones, and siltstones of probable Oligocen age. These pass upward into similar rocks of Miocene age with no apparent stratigraphic or structural break. The rocks of the upper part of the Oligocene section are also well exposed at the mouth of the canyon of the Riviere Blanche. In this vicinity the rocks are chiefly sandy and clayey limestone interbedded with sandy siltstone and claystone.

The entire thickness of the Oligocene is not exposed in the map area of plate $I$. However, it is probable that the Oligocene is at least several hundred meters thick in the Cul-de-Sac region. Moreover, it is 
probable that sediments representing each of the three divisions of the Oligocene series are present in the region, although fossils of definite lower Oligocene age have not been described.

The rocks of the Oligocene series, in common with the underlying Eocene rocks, are folded in large compound anticlines and synclines in the northern part of the Massif de la Selle and apparently also in the southern part of the Montagnes du Trou d'Eau. The axis of the larger folds generally trend west - northwest.

Where exposed in the canyons of the Rivières Grise and Blanche, and In the large ravines on the north slope of the Massif de la Selle, Oligocene limestones are commonly crumpled in minor folds superimposed on the limbs of the larger structures. In places where deformation has been most Intense these folds are overturned to the north and may pass into high-angle thrust faults. Along the northerm limit of these mountains the Oligocene rocks generally dip steeply northward at angles ranging from 30 to 80 degrees.

The structure of the Oligocene rocks on the south slope of the Montagnes du Trou d'Eau is somewhat obscure owing to the lack of outcrops and the massive bedding of the limestones. The Oligocene rocks along the southerm margin of these mountains generally dip southward. However, the dips of the rocks appear to be generally flatter than those on the northerm margin of the Massif de la Selle.

Oligocene limestones are the source rocks of practically all the springs along the northern and southern margins of the Cul-de-Sac Plain. Ground water circulates through the limestones in two ways: (1) in channels and cavernous zones formed by the dissolution of soluble parts of the rock, and (2) in joints and other secondary fractures and along the bedding planes. 
In the massive facies of the limestone the ground water appears to move chiefly in well-defined solution channels formed by the dissolution and enlargement of joints-especially along the lines of intersection of different jolnt systems. The thin-bedded limestones are commonly sheeted, owing to the compressive stresses that the rock has undergone. Through such rock ground water may circulate over areas of considerable lateral extent along bedding planes and in joints and sheeted zones.

Practically all the springs that issue from the Oligocene limestones rise either in ravines cut in the lower slopes of the bordering mountain ranges or at the edge of the alluvium of the Cul-de-Sac Plain. Some 20 springs or spring groups that rise from Oligocene rocks were observed during the present study. These discharge at rates ranging from a fraction of a liter per second to more than 500 liters per second. These springs are described in detail in table 4. Typical examples of springs Issuing from Oligocene limestone are Sources Manneville, Source Trou Caiman, and Sources Frères. Sources Manneville (No. 16) are located, about 5 kilometers southeast of Thomazeau near the Etang Saumâtre. These springs rise from small solution passages and jolnts in massive gray limestone and limestone conglomerate at the contact of the Oligocene with Recent alluvium. In the group there are two major and two minor spring heads along a line about 50 meters long. The flow of the springs during 20 years of measurement has ranged from 323 to 690 liters per second. Th1s spring group is the second largest of the Cul-de-Sac region.

Source Trou Caiman (No. 12) is located about 4 kilometers west of Thomazeau. The spring rises in 5 to 10 small orifices along a line about 8 meters long. The flow appears to issue from a bedding plane in lime- 
stone enlarged by solution near the contact of the Oligocene with Recent alluvium. The discharge of the spring during some 7 years of measurement has ranged from 12 to 40 liters per second.

Source Frères (No. 29) rises near the head of a small ravine about 3-1/2 kilometers east of Pétionville. The spring issues from a single tubular solution channel about 1 meter in diameter. This channel has apparently been formed by solution at the intersection of joints in Oligocene limestone directly underlying a cover of lime-cemented Pleistocene gravels. The average flow of this spring is probably about 60 liters per second.

The clastic claystones, siltstones, and sandstones that occur in the upper part of the Oligocene section are probably not highly pervious to the movement of ground water. For this reason it does not appear likely that these sediments would give rise to springs of appreciable size. None was observed during the present study.

The Oligocene rocks that crop out on the flanks of the mountains bordering the Cul-de-Sac Plain probably underlie the Miocene and younger rocks beneath the lowlands of the plain. However, they have not been reached by any water wells drilled in the plain. Deep test wells drilled in the triangle between Port-au-Prince, Pétionville, and Croix-des-Bouquets by the Atlantic Refining Company suggest that Oligocene rocks may lie at depths of 500 meters or more beneath the lowlands of the plain.

\section{Miocene Series}

In the Cul-de-Sac region sediments of Miocene age underlie all the lowlands of the plain and the foothill areas along the base of the Massif 
de la Selle. However, with the exception of outcrops of limited extent in the foothill areas, the Miocene rocks are everywhere covered by younger deposits. The outcrops of Miocene rocks observed during the present study are shown in plate I. Other outcrops not observed may occur in those areas mapped as Pleistocene, especially in the foothills near Port-au-Prince and Pétionville.

Miocene sediments in the Cul-de-Sac region are prevailingly clastic, although calcareous strata also occur in the series. The best exposures of the rocks in the region were found along the Port-au-Prince - Pétionville road and in the new road under construction from the Port-au-Prince airport to Pétionville. The Miocene sediments are semiconsolidated thin-bedded claystone, siltstone, sandstone, and conglomerate, with some marl and limestone. Most of these sediments, or at least the clastic facies, were probably deposited in shallow offshore marine waters. The sandstone and conglomerate are commonly cross-bedded and channeled, suggesting that they were laid down in the littoral zone. The pebbles in the conglomerates are principally of Oligocene or Eocene limestones, but pebbles of Cretaceous basalt also are present. These pebbles were evidently deposited in the Miocene sea by streams draining old lands in the regions of the present Massif de la Selle and Montagnes du Trou d'Eau. None of the individual members of the Miocene series appears to extend over a wide area. Conmonly individual strata pinch out or grade into one another within a few score meters along the strike.

The Miocene rocks exposed on the southern side of the Cul-de-Sac Plain contain an abundant fossil fauna of more than 49 recognized I/ species principally mollusca and corals but also including echnoids, bryozoa, and foraminifera. The large plicate oyster Ostrea haitensis, typical of the I/ Woodring, Wendell P., Brown, John S., and Burbank, Wilbur S., op. cit., pp. $221-223$. 
Miocene, was observed by the writers in a number of different localities near Port-au-Prince.

The total thickness of Miocene rocks is not exposed in the Cul-deSac region but at least several hundred meters of the serles is exposed in cuts along the Port-au-Prince - Pétionville road. Deep test wells drilled by the Atlantic Refining Co. near Pétionville are reported to have penetrated 500 meters or more of Miocene sediments. In the lowlands of the Cul-de-Sac Plain a number of deep water wells drilled by the Haitian American Sugar Company pass through 100 to 150 meters of Miocene sediments.

The Miocene rocks are apparently folded. In most of the Cul-de-Sac region. Folding has been most intense in a belt about 5 to 6 kilometers wide that lies along the northerm base of the Massif de la Selle and that extends east from Port-au-Prince to Ganthier. In this belt the Miocene rocks are strongly to steeply tilted in almost every outcrop observed, and in places the rocks are crumpled or overturned. Beneath the central lowland area of the plain the Miocene rocks appear to be only gently folded or perhaps in places even flat lying.

Because of their heterogeneous physical character the Miocene rocks show considerable diversity in their water-bearing properties. The claystone, siltstone, and marl strata of the Miocene series are generally compact, fine-textured rocks that will yleld little or no water to wells even where present in the zone of saturation. On the other hand, the sandstones and conglomerates may be moderately to highly permeable, depending largely on their degree of sorting and induration. The limestones where fractured and traversed by solution passages may also be moderately permeable. 
Beneath the central lowland area of the plain the rocks of the Miocene series are only gently folded or flat lying and contain productive water-bearing strata. However, the Miocene strata in the strongly folded belt along the south side of the plain are essentially unproductive. Probably as a consequence of the intensity of the folding in this belt the Miocene rocks have been considerably indurated. Even the conglomerates and sandstones appear to have lost much of their original permeability and in places may be almost impermeable. Moreover, because of the close folding of the Miocene rocks ground-water circulation through these strata is impeded or takes place with difficulty.

The unproductive character of the Miocene strata in the belt of strong folding has been demonstrated by wells drilled to depths of 40 to 375 meters. Some 50 test wells ranging in depth from about 150 to 375 meters were drilled by the Atlantic Refining Co. in the foothills near Port-au-Prince and Pétionville. These wells passed through considerable thicknesses of strongly folded Miocene conglomerates and sandstones. It is reliably reported that most of these strata were dry or contained only meager quantities of highly mineralized or brackish water.

Similar conditions have been encountered in other wells drilled by the Haitian American Sugar Co, in strongly folded Miocene rocks. Well 7 (see table 5), about 3-1/2 kilometers northeast of Port-au-Prince, was drilled to a depth of 187 meters and encountered only small quantities of mineralized water in Miocene conglomerates and limestones at 50, 149, and 152 meters below the surface. The yield obtained from the well was only 0.1 liter per second. Negative results were also obtained in well 72 (depth 41 meters) at the HASCO mill and in well 73 (depth 141 meters) at 
the HASCO residence area. Both of these wells were drilled largely in strongly folded Miocene rocks. Well 72 produced only a little salty water, and well 73 yielded practically none at all.

The belt of strongly folded, unproductive Miocene rocks extends eastward from the foothills near Port-au-Prince and Pétionville and passes beneath the alluvial fans of the Rivières Grise and Blanche and smaller streams to the foothills west, southwest, and south of Ganthier. Wells 42 and 43 at the HASCO Bauduy plantation about 6 kilometers east-northeast of Pétionville were drilled to depths of 62 and 169 meters, respectively. Beneath a cover of younger alluvial deposits both wells penetrated a considerable thickness of Miocene conglomerates and sandstones intercalated with claystones and siltstones. None of these strata produced water in quantity sufficient for irrigation and the wells were abandoned and destroyed. Farther east, at the HASCO Peyrard plantation about 6 kilometers east-southeast of Croix-des-Bouquets, wells 4 and 6 were put down to depths o: 88 and 171 meters, respectively. Both wells penetrated Miocene strata underlying younger deposits, but productive water-bearing beds were not encountered in the Miocene rocks.

In contrast to the unfavorable conditions that prevail in the belt of strong folding, the Miocene series beneath the central lowland area of the plain contain several productive water-bearing strata. These yield moderate to large quantities of water to drilled wells at depths ranging from about 70 to 165 meters below the land surface. The most productive water-bearing strata are semiconsolidated conglomerates and sandstones, which are generally logged as gravel and sand by drillers. These waterbearing strata or aquifers ranke from a few centimeters to about 8 meters 
thick, but the general range of thickness is about 2 to 5 meters. Thin water-bearing limestones are penetrated in some localities by wells, but generally these strata are not as productive as the sandstones and con'glomerates. All the aquifers of the Miocene series are intercalated with considerable thicknesses of impervious and unproductive claystone and siltstone. Few of the individual aquifers of the Miocene serles appear to extend over a wide area. Commonly between wells located only a few tens of meters apart individual aquifers may wedge out completely or may thicken or thin markedly.

A large number of well's have been drilled by the Haitian American Sugar Co. in the lowland area of the Cul-de-Sac Plain. Practically all these wells end in Miocene rocks. Moreover, most of the wells develop water from aquifers in overlying Recent and Fleistocene sediments as well as from those in the Miocene. Apparently the: only wells that develop water exclusively from Miocene aquifers are vells 51 and 57 at the HASCO Dessources plantation and well 61 at La Morinière plantation. In these wells the Recent and Pleistocene aquifès are cased off. Typical of the Dessources wells is well 53, which is 172 meters deep. Water-bearing Miocene strata were encountered at 60 meters in limestone, at 85 meters in sand or sandstone, and at 133 meters in limestone. In November 1948 the well was flowing about 1 liter per second at the land surface, but when first drilled in 1921 the well flowed 3.3 liters per second. Much of the diminution in flow is probably due to clogging of the well because 1t is uncased below 60 meters. Well 61 is 189 meters deep and obtains 1ts principal production from a Miocene sandstone lying between 129 and 132 meters below the surface. The well was capped in November 1948, but when 
first drilled in October 1920 it flowed 31.6 liters per second at the surface. Both wells 53 and 61 would undoubtedly yield larger quantities of water if they were pumped.

Because most of the wells that tap Miocene aquifers also obtain water from overlying Pleistocene and Recent aquifers, it is difficult to judge the relative productivity of the individual aquifers. However, it is probable that because of their greater consolidation the Miocene aquifers are generally less productive than those in the overlying Pleistocene and Recent deposits. Geologic and hydrologic data for individual wells drilled by the HASCO in the lowland area of the Cul-de-Sac Plain are given in detail in tables 5 and 6 .

\section{Pliocene (?) Series}

North and northeast of Ganthier is an area of low hills and bluffs whose surface rock is principally soft cavernous coralline and molluscan reef limestone. In places lenses of sand, gravel, and coquina appear to be interbedded with the limestone. These rocks were considered by Woodring, Brown, and Burbank I/ to be Quatermary, although it was recognized that the fossil evidence was not conclusive. Later work by geologists of the Atlantic Refining Co, has indicated that the rocks are more probably Pliocene.

The Pliocene (?) limestone contains an abundant fossil fauna, mostly poorly preserved corals and mollusca. Several species of corals were identified 2/ near Balan-namely, Stephanocoenia intersepta (Esper); Dichocoenia stokesi Milne-Edwards and Haime; Solenastrea bournoni Milne-Edwards and Haime; and Maeandra areolata (Linnaeus). The mollusks are generally too poorly preserved to be identified.

If Op. cit., p. 246.

2) Idem, p. 250 . 
The Pliocene (?) strata are undeformed and without perceptible dip. In the Ganthier area they rest unconformably on an erosion surface cut in folded Miocene rocks. The Pliocene (?) rocks may extend beneath Recent and Pleistocene deposits in the lowland area of the plain, although they were not distinguished in well logs. At least in their area of outcrop near Ganthier the Pliocene ( 3 ) rocks probably have a maximum thickness of no more than a few tens of meters. In most places in this area they appear to form a relatively thin reef cap resting on folded rocks.

No wells were observed that develop water from Pliocene rocks in the Ganthier area. Although the cavernous limestone, gravel, and coquina beds would probably yield moderate supplies of water to wells if present in the zone of saturation, it is probable that these beds are generally above the regional water table in the Ganthier area and are therefore unsaturated.

\section{Quaternary System}

\section{Pleistocene Series}

Sediments of probable Pleistocene age lie at the surface over areas of considerable extent on the south side of the Cul-de-Sac Plain and in limited areas on the north side. The areas of outcrop are shown in plate I, Along the northern and southern margins of the plain the Pleistocene deposIts are stream-laid semiconsolidated gravel and sand interbedded with some silt and clay. These deposits were derived from the eroded and weathered products of the rocks in the bordering mountains. Most of the pebbles in the gravels are of limestone, although some are of basalt. Commonly at the surface the Pleistocene deposits are capped by a hard layer of 
caliche or secondary calcium carbonate, and the gravels are cemented by a limy matrix.

The Pleistocene deposits along the borders of the plain form dissected alluvial fans that rest unconformably on an irregular erosion surface cut in folded Miocene or Oligocene rocks. In the foothill area near Pétionville and Port-au-Prince, Pleistocene deposits form an almost continuous blanket that covers strongly folded Miocene rocks. In places in this area the Miocene rocks are at the surface, but generally they are covered by Pleistocene deposits that are from a few meters to as much as 40 meters thick. Miocene rocks also appear to underlle almost continuous covers of Pleistocene deposits in the ridge about 4 kllometers east of Croix-desBouquets and in the foothills west and south of Ganthier.

The Pleistocene stream deposits of the borders of the plain apparently extend beneath younger Recent deposits of the central lowland area of the plain and rest unconformably on Miocene rocirs. In places in the lowland area the Pleistocene stream deposits appear to interfinger with soft marine fossiliferous marl, clay, and sand. However, beneath the central lowland the Pleistocene deposits cannot be definitely distinguished from overlying Recent deposits because the physical character of both is very similar.

The water-bearing properties of the individual members of the Pleistocene series depend chiefly on their lithologic character and topographic position. The clays, silts, and marls generally have low permeability and yleld little or no water to wells. On the other hand, the gravels and sands have moderate to high initial permeability, but this may have been reduced subsequently by compaction or cementation.

In the foothill area near Pétionville and Port-au-Prince, the Pleistocene gravels and sands have lost most of their original permeability by 
secondary cementation. Moreover, they are much dissected by small ravines and probably are generally rather thoroughly drained. However, in the localities where they are least dissected and in the large ravines, they may yield water sufficient for stock and domestic purposes to shallow wells. At well 7, for example, a water-bearing stratum of sand and gravel, apparently in the Pleistocene, was encountered between 33.8 and 34.4 meters below the surface. The yield of this stratum was evidently small. At Sources Puits Blanc (No. 37) is a natural well in semiconsolidated Pleistocene gravel located in a small ravine. During the wet season this well overflows as a spring, but in the dry season the water level declines to about 2 meters below the surface. Other small springs are reported to exist in the large ravines draining west-northwest from the vicinity of Pétionville.

In the foothills east of Croix-des-Bouquets, and in the dissected alluvial fans on the north side of the plain, the Pleistocene deposits are compact and well cemented. Most of the Pleistocene deposits in these areas are probably above the regional zone of saturation.

A considerable thickness of Pleistocene deposits underlies the Recent of the central lowland, but the deposits of the two series are difficult to differentiate. Some aquifers classified as Recent in tables 5 and 6 may be Pleistocene, and vice versa. Beneath the central lowland the Pleistocene sands and gravels are apparently uncemented and fairly well sorted and hence are more permeable than their counterparts in the foothill areas and in the dissected alluvial fans. One or more strata of water-bearing sand and/or gravel of the Pleistocene series have been penetrated in practically all the wells drilled by HASCO in the central lowland of the plain. Most of these 
strata appear to $11 \mathrm{e}$ in a range of about 20 to 70 meters below the land surface. Like similar strata in the overlying Recent series, the waterbearing strata of the Pleistocene are moderately to highly product1ve. The characteristics of Individual wells that tap Plelstocene as well as Recent aquifers are discussed in the section that follows.

\section{Recent Series}

Directly underlying the central lowland of the plain and the young alluvial fans of the Rivières Grise and Blanche and smaller streams around the borders of the plain is Recent alluvium whose areal extent is shown in plate I. The Recent alluvium consists of unconsolidated stream-laid clay, silt, sand, and gravel deposited in irregular lenses and stringers that dovetail into one another in a complex fashion.

In the upper and higher parts of the alluvial fans the alluvium is principally coarse-textured gravel with some sand. The lower parts of the alluvial fans are made up of about equal amounts of interbedded gravel and sand with some silt and clay. The Recent alluvium beneath the central lowland of the plain is mostly interstratified clay, silt, and sand, although beds of fine gravel are also present.

Among the sedimentary facies of the Recent alluvium the silts, clays, and fine sands are too tight and impermeable to yield much water to wells. On the other hand, the interbedded well-sorted sands and gravels are moderately to highly permeable.

Practically all the HASCO wells drilled in the Cul-de-Sac Plain tap water-bearing strata of sand and/or gravel in the Recent alluvium as well as aquifers in the underlying Plelstocene and Miocene deposits. The HASCO 
wells tap from one to four aquifers in the Recent alluvium. The individual aquifers range from about 1 to 8 meters thick and are generally separated by considerable thicknesses of impervious clay or silt.

The Recent alluvium contains the most productive aquifers in the plain. Most of these are tapped by wells within a range of a few meters to about 60 meters below the land surface. For example, well 3 at the HASCO Vaudreuil plantation yields 35.3 liters per second with the static water level at the land surface and the pumping level 12.8 meters below the surface. The well is 52.4 meters deep and obtains its supply from Recent sand and gravel aquifers at $38.7,45.1$, and 47.9 meters below the surface. Another example is well 20 (HASCO Sibert "A" No. 2), which is 61 meters deep and taps water in sand and gravel at depths of 16.8, 39.6, and 48.8 meters. This well yields 38.6 liters per second with the static water level 0.9 meter below the land surface and a drawdown of 14.2 meters. In other wells in the plain that tap aquifers in Recent alluvium yields of 30 to 100 liters per second are commonly obtained. The characteristics of individual wells that develop water from aquifers in the Recent alluvium as well as in underlying Pleistocene and Miocene aquifers are shown in tables 5 and 6.

The Recent alluvium also gives rise to a considerable number of springs that are essentially outcrops of water table in the uppermost aquifer of the alluvium. Typical are Sources Cazeau (No. 1), which Issue. from five spring heads and general seepage in Recent unconsolidated coarse sand and pebble gravel. The springs rise in a ravine 1 to 3 meters below the level of the plain in a line about 300 meters long. The average aggregate discharge of these springs is 50 liters per second. Some 16 springs 
or spring groups that 1ssue from Recent alluvium were visited during the present study. These discharge at a rate ranging from a few liters to as much as 700 liters per second and are described individually in table 4.

\section{SUMMARY OF GEOLOGIC HISTORY}

The geologic history of the Cul-de-Sac region includes a rather long and complex sequence of events whose detalled description is not within the scope of this report. However, a general summary of these is given below:

1) In late Cretaceous time extensive fissure eruptions of basalt flows in the region of the Massif de la Selle and possibly in the Cul-de-Sac region. Basalt flows in part erupted on dry land and in part in shallow marine waters where the flows were intercalated with marine limestones, shales, and sandstones.

2) Folding and uplift at the end of Mesozolc time.

3) Extensive erosion in early Eocene time.

4) Submergence in middle Eocene time.

5) Transgression of a late Eocene sea in the Cul-de-Sac and adjacent regions with deposition of a thick sequence of limestones.

6) Emergence and some folding at the end of Eocene time.

7) Some erosion in early oligocene time.

8) Submergence and transgression of a middle Oligocene sea with, first, deposition of limestones and then intercalated limestones, claystones, and siltstones with some sandstones and conglomerates. Local eruptions of nepheline basalt flows such as that near Thomazeau.

9) Uplift and erosion of regions bordering the Cul-de-Sac Plain in late Oligocene time. 
10) Transgression of a Miocene sea into the Cul-de-Sac region, with extensive deposition in the littoral zone of sandstones and conglomerates from detrital materials brought in by streams from bordering land masses and deposition in the deeper, quieter waters of limestones, claystones, and siltstones. 11) During late Miocene and/or Pliocene time extensive folding of Miocene and older rocks with down-warping of the Cul-de-Sac trough and the up-arching of the Montagnes du Trou d'Eau and the Massif de la Selle. Followed or accompanied by high-angle thrust faulting, especially along the southern flank of the Cul-de-Sac trough, with close folding, crumpling, and overturning of rocks in the fault zones. Also high-angle thrust faulting along the north flank of the trough.

12) Extensive erosional planation of folded and faulted Miocene and. Oligocene rocks along the borders of the Cul-de-Sac trough and possibly also in the present lowland area of the plain during Pliocene time. 13) Probably in late Pliocene time an invasion of a shallow sea into the Cul-de-Sac trough with deposition of reef limestones in the Ganthier area. 14) Continued submergence in Pleistocene time of the lowest parts of the Cul-de-Sac trough. Active stream erosion in bordering mountain ranges with deposition of the detrital materials in extensive subaerial alluvial fans along the flanks of the trough and of marine clays, marls, sands, and gravels in submerged parts of the trough.

15) Emergence of the Cul-de-Sac trough about the end of Pleistocene time. 16) Dissection of Pleistocene alluvial fans and continued stream erosion in mountain areas. Deposition of the detrital materials in Recent alluvial fans and fill extending across the lower parts of the Cul-de-Sac trough recently emerged from the sea. 
GROUND WATTER

\section{General Features}

The ultimate source of the ground water that occurs in the rocks of the Cul-de-Sac region is rainfall. A part of this runs of in streams to the sea, a part returns directly to the atmosphere by evaporation, but a considerable part percolates down through the rocks to the zone of saturation. Once in the zone of saturation the water moves slowly underground in permeable strata and is discharged through wells and springs, evaporation and transpiration, and submarine springs.

Three principal systems of ground-water circulation appear to exist In the Cul-de-Sac region. For purposes of description these are designated (1) the northern system, (2) the southern system, and (3) the central system. The characteristics of each of these are described beyond.

\section{Northerm System}

The north side of the Cul-de-Sac Plain is bordered by Oligocene limestones that form the southerm slopes of the Montagnes du Trou d'Eau. These rocks contain a zone of saturation that is largely cut off underground from the central system of the plain by faults.

The Oligocene limestones receive water at the surface by direct infiltration of rainfall and also by infiltration from streams draining the southern slope of the Montagnes du Trou d'Eau. The water thus received percolated down to a zone of saturation where it moves underground along the slope of the water table. Beneath the southern flank of the Montagnes du Trou d'Eau the water table appears to slope southward, governed to a large extent by the southward dip of the Oligocene rocks. Water from the zone of 
saturation is discharged by springs at the surface or it leaks underground into rocks of the central system.

The springs that issue from 0ligocene rocks of the northern system are shown in plate I. Most of these springs are fed by meteoric nonthermal water whose temperature ranges from $24^{\circ}$ to $28^{\circ} \mathrm{C}$. Sources Puantes (No. 7) and Source Ca Secant (No. 9), however, are thermal springs which appear to be fed by connate water I/ that rises from depths of the order of 175 meters along a fault line. The temperature of Sources Puantes is $33^{\circ} \mathrm{C}$. and that of source $\mathrm{Ca}$ Secant is $36^{\circ} \mathrm{C}$.

The total average discharge of the nonthermal meteoric springs that issue from the Oligocene limestones of the northern system is roughly 850 liters per second. However, these springs show considerable variation In flow from season to season and from year to year. The discharges of most of the springs have varied from the average as much as 50 to 100 per cent or more during the past 20 years. Source Trou Caiman (No. 12), for example, has fluctuated between measured discharges of 12 and 40 liters per second. Sources Manneville (No. 16) have ranged between measured discharges of 323 and 690 liters per second. These fluctuations in discharge directly reflect the quantity of infiltration received by the zone of saturation in the northerm system. All the meteoric springs show increased flow toward the end of the fall rainy season and the beginning of the dry season. There Is a gradual decline in flow during the dry season which continues into the next spring rainy season until ground-water storage is replenished.

\section{Southern System}

On the south side of the Cul-de-Sac Plain are Oligocene limestones whlch form the north flank of the Massif de la Selle. These rocks also I/ Woodring, Wendell P., Brown, John S., Burbank, Wilbur S., op. cit., p. 557. 
contain a zone of saturation that is largely cut off from the central system of the plain by faults and by the belt of strongly folded Miocene rocks along the southern border of the plain. The zone of saturation in the Oligocene rocks is replenished in much the same manner as that of the northern system. However, as a consequence of greater rainfall in the Massif de la Selle, the zone of saturation of the southern system may receive a greater annual replenishment than that of the northern.

The water in the zone of saturation apparently moves northward, following the slope of the water. table and the northward dip of the Oligocene rocks. It is discharged from this zone by springs and perhaps by some underground leakage into rocks of the central system. Some 14 springs or spring groups that issue from Oligocene rocks of the southern system were visited during the present study. These are shown in plate $I$ and described in detail in table 4. The water temperatures of the springs range from $19^{\circ} \mathrm{C}$. to $23^{\circ} \mathrm{C}$., indicating that they are all nonthermal and of meteoric origin. These temperatures are substantially lower than those of springs of the northerm system. The difference may possibly be attributed to the higher elevation of the Massif de la Selle and the consequent lower atmospheric temperatures in the intake areas of the southern system. As indicated in the section on "Climate," there appears to be a lowering of about $I^{\circ} \mathrm{C}$. In the mean annual temperature for each increase of 150 meters in altitude above sea level.

The average total discharge of the springs issuing from the Oligocene limestones of the southern system is roughly 450 liters per second. In addition, a considerable part of the base flow of the Rivières Grise and Blanche is supplied by springs that issue from Oligocene limestones in the 
canyons of these streams. As in the northerm system, the springs vary in discharge from season to season and from year to year. Variations from 50 to 100 percent or more of the average discharge have been observed in these springs. These variations reflect replenishment to ground-water storage in the zone of saturation during rainy seasons and depletion by spring discharge in the dry seasons. The nature of the variation in spring discharge of the southern system is much the same as that of the northerm.

\section{Central System}

\section{$\underline{\text { Recharge }}$}

The aquifers of the Recent alluvium as well as those of the underlying Pleistocene deposits and the slightly deformed Miocene strata of the central lowland of the plain appear to be interconnected and constitute a single system of ground-water circulation. This is designated the central system for purposes of discussion in this report.

The aquifers of the central system are sustained and perennially replenished by water derived from several sources. These are: (1) direct infiltration from rain that falls on the surface of the plain (2) infiltration from streams that enter the plain from the bordering mountians,

(3) seepage from irrigation, and (4) underground leakage from the northern and southerm systems. These sources of recharge were not evaluated quantitatively during the present study, but the relative importance of each is discussed beyond.

The average annual precipitation over the lowland area of the plain ranges from about 750 to 1,100 millimeters. Most of this generally occurs during the months of April, May, and June and August, September, and October. 
These constitute the spring and fall rainy seasons. A part of the water that falls as rain runs off in streams to the sea or to Etang Saumâtre, a part returns to the atmosphere by evaporation or by transpiration of plants, but a considerable part percolates down to recharge the aquifers of the central system. The amount of water recelved by the central system in this manner is not precisely known. However, if it were as little as 10 percent of the rainfall, the average annual recharge recelved by direct infiltration from rain would be of the order of 2,430 to 4,000 hectare-meters over the 36,400 hectares of the arable area in the plain.

Aquifers of the central system also receive important recharge by infiltration from streams that enter the plain from the bordering mountians. By far the most important of the streams are the Rivières Grise and Blanche. As based on 18 years or record, the mean annual munoff of the Rivière Grise is about 12,846 hectare-meters and that of the Rivière Blanche is about 5,512 hectare-meters. The base flow and the dry-season discharge of the Rivières Grise and Blanche are all diverted for irrigation. However, most of the flood discharge of the Rivière Grise in the rainy seasons runs off to the sea. In major floods water from the Rivière Blanche reaches the Eaux Gaillées depression where it is dissipated by evaporation or by transpiration of plants. However, in minor floods most of the flow of the Riviere Blanche seeps away underground in the permeable deposits of its alluvial fan. The most important recharge to the aquifers of the central system occurs when these streams are in flood and there is active percolation from the stream channels. Most of the percolation takes place in the coarse permeable gravels and sands of the upper and middle parts of the alluvial fans. It is belleved that infiltration from the Rivières Grise and Blanche and other 
streams entering the plain from the bordering mountains is possibly the principal. source of recharge to aquifers of the central system.

Seepage from irrigated fields also constitutes an appreciable if not important source of recharge to aquifers of the central system, especially during the dry seasons. Irrigation is practiced by diversions from the Rivières Grise and Blanche, from springs that overflow from the northern and southern systems of Oligocene rocks, from springs that issue from aquifers of the central system itself, and by pumping from wells in aquifers of the central system. Seepage return may thus be recelved from a total of about 26,504 hectares of irrigated land.

Some water may enter aquifers of the central system by underground. leakage from Oligocene limestone aquifers of the northerm and southerm systems, but the extent to which this occurs is difficult to evaluate. Along the southern flank of the plain, Oligocene rocks are faulted against strongly folded Miocene strata. It is believed that the belt of strongly folded Miocene rocks acts as a barrier to the northward movement of ground water from the Oligocene limestones. This barrier tends to force the water of the southern system to the surface in springs. Somewhat similar conditions appear to prevail along the northerm flank of the plain, although the structural relations of the rocks in this zone are not clear.

\section{Ground-Water Circulation}

As previously mentioned, the Recent, Pleistocene, and Miocene aquifers of the central part of the Cul-de-Sac Plain are apparently interconnected and constitute a single hydrologic system of ground-water circulation. However, the pattern of circulation through individual aquifers is somewhat obscure. The deep Miocene aquifers beneath the central lowland of the plain 
are evidently recharged principally by deep percolation of water through overlying Pleistocene and Recent deposits. It is improbable that much recharge is received by the Miocene aquifers from the Miocene rocks of the belt of strong folding, which impedes rather than facilates the lateral movement of ground water. The Pleistocene aquifers underlying the Recent alluvium of the central part of the plain likewise receive recharge by deep percolation from overlying deposits. The aquifers of the Recent alluvium are the first to be recharged by infiltration from the surface, and apparently when these are replenished the excess water percolates down to the deeper aquifers in Pleistocene and Miocene deposits.

The ground water in the aquifers of the central system occurs under water-table or unconfined conditions as well as under artesian or confined conditions. All aquifers in the Miocene and Pleistocene deposits are confined. The deeper aquifers of the Recent alluvium are also confined, but the uppermost aquifers are under water-table conditions.

Sufficient data were not available to map the position and slope of the water table or of the piezometric surfaces of the deep aquifers. The water table in the Recent alluvium appears to slope northward through the alluvial fans of the Rivières Grise and Blanche almost to the base of the Montagnes du Trou d'Eau. From the vicinity of La Morinière and La Serre plantations it is probable that the water table in the lowest axis of the plain slopes westward to Port-au-Prince Bay and eastward to the Etang Saumâtre. Ground water at least in the uppermost aquifer of the Recent alluvium moves generally along the slope of the water table. 


\section{Discharge}

The discharge of ground water from the central system takes place in a number of ways, most important of which are: (1) direct evaporation from the water table or from the capillary fringe, (2) transpiration by plants, (3) discharge by springs and drains, (4) pumpage from wells, and (5) spring discharge in the sea and in Etang Saumâtre. During the present study it was not possible to evaluate each of these discharge sources quantitatively, but the relative importance of each is described beyond.

Ground-water discharge by evaporation occurs where the water table is at the surface or the capillary fringe from the water table extends to the surface. In the Eaux Gaillées depression and in an area between Rendez-Vous and La Serre plantation (see pl. I) the water table is at the surface in swampy tracts. As suggested in the section on "Climate" the annual evaporation from a free-water surface in the Cul-de-Sac Plain may be of the order of 2,115 millimeters: thus considerable quantities of ground water are returned to the atmosphere by direct evaporation, especially during the dry seasons. Adjacent to the swampy tracts are extensive areas of salt-encrusted ground where the water table is generally within about 2 meters of the surface. In these areas the capillary fringe evidently extends to the surface, and salt is precipitated from water that rises to the surface by capillar1ty and evaporates.

Large parts of the lowland area of the plain are overgrown with thickets of bayahonde and other thorny leguminous scrub growth. A number of species of these plants are phreatophytes. They subsist on water derived from the zone of saturation and may send down roots several meters to the water table or to the capillary fringe. Judging from the density and large areal extent 
of this type of plant growth in the plain, the quantity of ground water discharged to the atmosphere by transpiration must be of considerable magnitude.

Ground water in large quantity is discharged from the central system by springs and by artificial drains. The springs rise from permeable sand and/or gravel of the Recent alluvium. All are apparently of the gravity depression type and are essentially outcrops of the water table. The springs of the central system may be divided into two groups: (1) those that rise in or along the edges of the Recent alluvial fans in the border areas of the central system, and (2) those that rise in lowland areas of the plain. Typical examples in the first category are Sources Duthil (No. 14) and Sources Depuzeau (No. 21). These springs rise at the lower edges of alluvial fans and may represent water that is not absorbed by aquifers of the central system--"rejected recharge." Springs in the second category are typified by Sources Cazeau (No. 1) and Source Lathan (No. 3). These represent essentially overflow of ground water that has circulated some distance through aquifers of the central system.

All the springs of the central system show seasonal fluctuation in discharge corresponding to the position of the water table. The discharges are greatest during the wet seasons when the water table is high and are smallest in the dry seasons when the water table is low. Springs that issue from the lower edges of the alluvial fans show the greatest range in seasonal fluctuations of discharge. Sources Despuzeau (No. 21), for example, have a mean discharge of 707 liters per second. However, the annual range of fluctuation in discharge may be 50 to 100 percent or more of the mean. Many of the higher spring heads in the group go dry in the 
dry season with the seasonal decline of the water table. The springs of the lowland area of the plain have a more constant discharge. The discharge of Sources Cazeau (No. 1), for example, shows seasonal fluctuations, ranging from 40 to 60 liters per second, but the average discharge is about 50 liters per second. The mean total discharge from the central system by springs and by spring-fed streams such as Rivière des Orangers and Rivière Despuzeau is approximately 1.5 cubic meters per second. The detailed characteristics of individual springs that rise from the central system are shown in table 4.

Two systems of open artificial drains also discharge water from the Recent alluvium in the lowest part of the plain. These drains were constructed to lower the water table in waterlogged lands and to carry off flood waters received by the lowland area during the rainy season. The drainage system of Ravine Boucan Brou (see pl. I) starts in the central part of the plain and drains west into Port-au-Prince Bay. That part of the flow supplied by ground-water seepage may be equivalent to a constant mean discharge of about 200 to 300 liters per second during the year. Another large drain extends east from the Eaux Gaillees depression to Etang Saumâtre. The discharge characteristics of this drain are not known. Ground water is also withdrawn artificially by wells from Recent, Pleistocene, and Miocene aquifers of the central system. The withdrawals from shallow wells for domestic and stock use are very small in quantity. However, wells of the HASCO withdraw considerable quantities of water from the central system by pumping and by artesian flow. The average annual pumpage from wells of the HASCO during the period 1942-47 was 14,726 acre-feet or 1,811 hectare-meters. This is equavalent to a constant discharge of 574 
liters per second over the period of a year. The total average discharge by artesian flow was about 50 liters per second during the same period. The total average discharge from wells of the HASCO was thus about 624 liters per second in the period.

There is doubtless ground-water discharge through submarine springs into Port-au-Prince Bay and also through springs at or below lake level in the Etang Saumâtre. It is probable that ground-water discharge from the deep Miocene aquifers of the central system occurs largely in submarine springs in Port-au-Prince Bay. Discharge from the aquifers of intermediate depth may take place indirectly by upward leakage through breaks in confining beds. The quantitative importance of submarine discharge or that into Etang Saumâtre is not known.

\section{Hydrostatic Head}

As previously described, the ground water in aquifers of the central system occurs under water-table or unconfined conditions as well as under artesian or confined conditions. Only the shallow near-surface aquifers in the Recent alluvium are under water-table conditions; all deeper aquifers are confined.

In that part of the lowland area of the plain with an elevation of less than 25 meters above sea level, the water table is within 15 meters of the land surface. In springs of the lowland area the water table reaches the surface, and in the general vicinity of these springs the water table 1s within a few meters of the land surface. The water table is at the surface in the Eaux Gaillées depression and in the swamp lying between RendezVous and La Serre. In the area lying between Eaux Gaillées and this swamp the water table is generally within a few meters of the surface. In the 
Recent alluvial fans the depth to water increases gradually from the lower edges to the highest apex. Southward from the Croix-des-Bouquets to Ganthier highway, the depth to the water table in the alluvial fans of the Rivieres Grise and Blanche increases from less than 10 meters to perhaps as much as 50 meters. The depth to water is probably generally greatest along the high southern border of the Cul-de-Sac Plain.

Generally below the uppermost water-bearing stratum, each successive aquifer shows an increase in hydrostatic head over that of the aquifer next above it. However, only in the deepest aquifers tapped by wells in the lowest parts of the plain does the hydrostatic head rise to the land surface and produce flowing wells. In none of the existing wells do the piestic levels of deep confined aquifers rise more than 10 or 12 meters above the static levels of the uppermost unconfined aquifers. Generally this difference is less than 5 meters in most of the wells in the plain. The maximum piestic head of the deepest aquifers tapped by existing wells is nowhere more than 5 meters above the land surface.

The nature of seasonal and annual fluctuations of the water table and of piestic levels in wells of the plain is know only in very general terms. Records of water-level changes in wells have not been systematically maintained and the period of the present investigation was too short to measure seasonal changes. Water levels in dug wells that tap shallow unconfined aquifers are observed to fluctuate seasonally, although the maximum annual range of fluctuation is no more than a few meters. The highest water levels occur toward the end of the rainy seasons and the beginning of the dry seasons. The lowest levels occur in the latter part of the dry season. The seasonal rise of water levels reflects gains in ground-water storage 
by recharge in the rainy seasons. The seasonal decline reflects depletion of ground-water storage through discharge of springs, wells, and drains, and by evaporation and transpiration.

Although the Haitian American Sugar Company has been pumping considerable quantities of ground water during the past 25 years, no significant downward trend in water levels in wells has been observed. In fact, water levels in most of the HASCO wells were substantially higher in November 1948 than they were during the decade 1920-30. As indicated in tables 5 and 6, the water levels in November 1948 were from 1 to 5 meters higher than when the wells were first drilled in 1920-30. This condition suggests that the annual recharge received by aquifers of the central system is more than sufficient to replenish the water withdrawn by pumping through the HASCO wells.

\section{WATER UTILIZATION}

Ground water for domestic and stock use he.s been extensively developed by means of shallow dug wells. It is estimated that there may be 300 or more such wells in the lowland area of the pla:tn. Most of the wells are less than 10 meters deep and usually extend no more than a meter or two below the water table. Practically all the wells are uncurbed and hence are easily subject to pollution from the surface. Most of wells are equipped with a simple hand line and bucket for drawing water.

The utilization of water from wells for irrigation is almost exclusively an enterprise of the Haitian American Sugar Company. In November 1948 the HASCO had 30 pumping plants in operation in the plain. Of these, 23 pumps were placed on simple drilled wells and 7 were installed at well batterles that include 5 to 20 wells per battery. In addition, there were 11 wells from which water for Irrigation was obtained by artesian flow. 
The yields of the simple wells equipped with pumps range from 11.5 to 130.5 liters per second and average 55.6 liters per second. The specific capacities of the individual wells range from 1.8 to 11.8 liters per second per meter of drawdown during pumping. The average specific capacity among the wells equipped with pumps is 4.5 liters per second per meter of drawdown. The yields of the individual batteries range from 23.1 to 96.4 liters per second and average 51.4 liters per second among the seven batteries in operation. Among 11 wells the individual yields obtained by artesian flow range from 0.1 to 23.1 liters per second and average about 4.5 liters per second per well.

During the past 25 years the annual pumpage from wells of the HASCO for the irrigation and processing of sugar cane has gradually increased. The total annual pumpage during the period 1942..47 from all the HASCO pumping plants, and the average cost per hectare-meter of water pumped are given below:

$\begin{array}{ccc}\text { Year } & \begin{array}{c}\text { Annual Pumpage } \\ \text { (Hectare-Meters) }\end{array} & \begin{array}{c}\text { Average Cost Per } \\ \text { (Hectare-Meter) }\end{array} \\ 1942 & 1,359.6 & \$ 26.73 \\ 1943 & 1,293.3 & 25.92 \\ 1944 & 1,880.7 & 23.33 \\ 1945 & 1,851.6 & 24.87 \\ 1946 & 2,127.0 & 24.22 \\ 1947 & 2,355.6 & 24.14\end{array}$

The average annual pumpage during this period was 1,811 hectare-meters, and the average cost per hectare-meter of water pumped was $\$ 24.87$. This is equivalent to a cost of about two-tenths of a cent for each cubic meter of 
water pumped. The cost per hectare-meter includes the actual operation and maintenance costs as well as the amortization of the costs of the pump and of drilling and casing the well.

In 1948 the Haitian American Sugar Company was cultivating 4,013 hectares divided among 38 plantations or estates scattered over the plain. The greater part of this land was irrigated from wells, although some plantations were irrigated by water from springs and streams.

During 1948, springs that issue from the northern, southerm, and central systems of the plain were used to irrigate by gravity ditch a total of 6,039 hectares, according to statistics of the Service des Eaux et Forêts. Of these some 4,454 hectares were irrigated from the combined discharge of Sources Babaco, Zabette, and Despuzeau (See table 4, Nos. 19, 21). Because of their unfavorable topographic position the discharges of Sources Manneville (No. 16) and Source Glore (No. 17) are not utilized for irrigation or for other beneficial purposes at present. However, plans are being made by a private enterprise to pump water from Sources Manneville for the Irrigation of about 800 hectares of land. Where data are avallable the areas irrigated from individual springs are shown in table 4.

Gravity diversions from the Rivières Grise and Blanche constitute the most important water supply for irrigation in the plain. In 1948 the total area 1rrigated from these two streams amounted to 16,482 hectares. Of these, 10,598 hectares were irrigated from the Rivière Grise and 5,524 from the Rivière Blanche.

In total there were some 26,504 hectares of land in the plain that recelved irrigation from wells, springs, and streams in 1948. The total arable area of the plain is 36,400 hectares, which leaves a difference of about 9,896 hectares of land that are essentially uncultivated and unproductive. 
However, considerable parts of those lands that lie under gravity ditch do not receive effective irrigation because of inadequacies in the systems of control and distribution, fluctuations in spring and stream discharge, and lack of storage facilities.

\section{CHEMICAL QUALITY OF GROUND WATER}

According to analytical data in the files of the Section de Chimie, Dept. de l'Agriculture, and of the Haitian American Sugar Co., most of the ground water in the Cul-de-Sac Plain is of the calcium bicarbonate type. Sulfate is reported to be low and chloride is also low except within 4 to 6 kilometers of Port-au-Prince Bay. The well waters in general are slightly more highly mineralized than spring waters, though the difference is not great. The water is generally very hard, and it has a moderate content of iron. The calcium bicarbonate breaks down readily with a rise in temperature or decrease in pressure. In the break-down process insoluble calcium carbonate is precipitated and carbon dioxide is liberated in gaseous form. Commonly difficulties occur through clogging of pipe lines by deposition of calcium carbonate. However, this characteristic does not generally affect the usefulness of the water for domestic, stock, or irrigation purposes.

Generally within 4 to 6 kilometers of the shore of Port-au-Prince Bay aquifers lying within about 20 to 30 meters of the surface yield water that is more highly mineralized than the average for the plain. In parts of this coastal zone with elevations of less than 5 meters above sea level the nearsurface aquifers yield brackish or even salty water that is unusable for Irrigation. However, aquifers at great depth yield mineralized but usable water. It has been suggested I/ that the ground water in aquifers of the 1/ Woodring, Wendell P., Brown, John S., Burbank, Wilbur S., op. cit., p. 545 . 
coastal zone is a mixture of the normal ground water of the plain with either connate water or sea water which may extend inland for several kilometers from the shore line. Most of the water from aquifers in this zone is higher in sodium and potassium chlorides, as well as being more highly mineralized, than that in the interior parts of the plain.

At the HASCO Sibert "A" plantation three aquifers containing warm salty water charged with hydrogen sulfide gas under pressure were encountered between 138.8 and 152.4 meters below the surface in well 33 . These saltwater aquifers produced an artesian flow of 12.6 liters per second. The well is located about 1,500 meters south of the fault along which rise the thermal springs of Sources Puantes (No. 7) and Source Ca Secant (No. 9). The water from these springs is also very salty and is charged with hydrogen sulfide. It is inferred that the ground-water body that supplies these springs may be the same as that tapped by well 33--at least, the springs and the well are interrelated geologically and hydrologically. The areal extent of the salt-water aquifers is not known. However, they probably extend at least under that part of the plain included in the triangle lying between Sources Puantes, Sources Ca Secant, and well 33 (See pl. I). 
FUTURE DEVELOPMENT OF GROUND WATER

The present geologic and hydrologic study indicates that the Cul-deSac Plain is the most promising area in Haiti for the future development of ground water for irrigation. From wells tapping aquifers underlying the western half of the lowland area of the plain, the Haitian American Sugar Co. is pumping an average of about 1,811 hectare-meters of water a year for irr1gation. The present study indicates that undeveloped aquifers of comparable productivity also underlie the eastern half of the lowland area. Moreover, large blocks of arable land in this part of the plain lie idle and unproductive for lack of water.

The block of land lying east of the Croix-des-Bouquets - Mirebalais highway, north of the Croix-des-Bouquets - Ganthier highway, south of Eaux Gaillées, and west of the Coustard and Cotin estates is considered to be particularly favorable for future ground-water prospecting and development. In this area yields of 30 to 130 liters per second can be obtained by tapping two or more aquifers in wells drilled to depths of 50 to 200 meters. The pumping lifts required in wells might be expected to range from about 10 to 25 meters. Individual wells would have specific capacities of about 2 to 10 liters per second per meter of drawdown in pumping. If wells are properly spaced in this area it is estimated that a total water supply of the order of 2,000 hectare-meters per year could be withdrawn without detriment to existing ground-water developments of wells and springs. A spacing of about 800 to 1,000 meters between production wells would seem sufficlent to avoid local overdevelopment and lowering of the water table.

As has been previously mentioned in the section on "Water Utilization," the Haltian American Sugar Co. has been pumping water from wells in the 
western part of the plain for more than 25 years. During this time the water levels in the wells have not changed significantly, and no general downward trend has been observed. From this it is inferred that the full capacity of the aquifers in the western part of the plain has not yet been reached. Further, it is believed that pumpage from existing wells in the westerm area could be increased considerably or additional production wells could be drilled in this area. If additional wells are put down they should be spaced far enough from existing wells to avoid local overdevelopment and lowering of water levels.

That part of the plain lying south of the Croix-des-Bouquets - Ganthier highway is not considered to be generally as fevorable for ground-water development as the area to the north. The Miocene rocks are strongly folded in much of this area and are essentially nonproductive, so that deep drilling to tap them for irrigation supplies is not considered worth while. The overlying deposits in the alluvial fans of the Rivières Grise and Blanche contain two or more aquifers of moderate productivity. Most of these aquifers lie within about 70 meters of the surface, but the yields of individual wells, in general, should not be expected to exceed 20 to 30 liters per second. Moreover, it is also to be expected that pumping lifts of the order of 25 to 40 meters would be required.

The foothill area between Port-au-Prince and Pétionville and 5 to 6 kilometers north and northeast of these cities is considered unfavorable for ground-water prospecting for irrigation supplies. However, small water supplies for domestic and stock use may be obtained from Pleistocene deposits by wells less than 25 meters deep located in the larger ravines of this area. 
In the foothills east of Croix-des-Bouquets, near Ganthier, and in the dissected alluvial fans on the north side of the plain conditions are not considered to be generally favorable for ground-water prospecting for irrigation.

A number of small irrigation systems are supplied by gravity from springs that rise in the lowland area of the plain. The yields of the springs could be considerably increased by improvements at the spring heads. Suggested improvements would include (1) cleaning out worthless aquatic vegetation from around the spring heads, (2) trenching of spring heads to gather diffused seepage, and (3) captation structures or small collecting tanks to regulate spring discharge. By these measures considerable water could be salvaged that would otherwise go to waste by transpiration and evaporation. In addition, more effective utilization of the available water could be made by improvements in ditches and methods of irrigation. Springs susceptible to such improvements are listed below:

$\begin{array}{llll}\text { Sources Papeau } & \text { (No. 2) } & \text { Sources Lagon } & \text { (No. 13) } \\ \text { Source Lathan } & \text { (N. 3) } & \text { Sources Greffin } & \text { (No. 31) } \\ \text { Source Balangnier } & \text { (No. 6) } & \text { Sources Duthil } & \text { (No. 14) }\end{array}$

The discharge of springs that issue from Oligocene limestones of the northern and southern systems along the borders of the plain could be increased by improvements at the spring heads. Short tunnels driven into the spring heads would tend to enlarge and clear the natural outlets and thereby facilitate ground-water discharge. Springs at which such tunnels could be constructed are listed below: 


$\begin{array}{ll}\text { Sources Hatte Dumornay } & \text { (No. 10) } \\ \text { Source Diacroix } & \text { (No. 11) } \\ \text { Sources Frères } & \text { (No. 29) } \\ \text { Source Métivier } & \text { (No. 38) }\end{array}$

By general improvements in ditches and irrigation methods and by construction of small regulatory tanks or reservoirs, the areas irrigated by most of the small spring-supplied irrigation systems of the plain could be considerably increased.

\section{CONCLUSIONS}

The Cul-de-Sac Plain is underlain by a ground-water body which has been partly utilized for irrigation but which has still greater potentialities for extended development and utilization. It is estimated that ground-water supplies are available to irrigate roughly 4,000 hectares of land in addition to that now under irrigation from wells.

The Haitian American Sugar Company is at present pumping an average of 1,811 hectare-meters of water a year from wells, most of which are located in the westerm part of the Plain. Ground water in the eastern part of the plain is essentially undeveloped. In the area lying north of the Croix-des-Bouquets - Ganthier highway, south of Eaux Gaillées, east of the Cro1x-des-Bouquets - Mirebalais highway, and west of the Coustard and Cotin estates, conditions are especlally favorable for future ground-water development by new wells. If new wells are properly spaced to avold mutual interference, it is estimated that roughly 2,000 hectare-meters of water a year could be withdrawn from the ground-water body in this area. 
The annual pumpage from existing wells could be increased or withdrawals from new wells could be made from the ground-water body in the western part of the plain. However, new wells would have to be placed far enough from existing wells to avold local overdevelopment. Water levels in the HASCO wells in this part of the plain have not shown any significant downward trend during the past 25 years in spite of moderately heavy pumping.

If new wells are properly spaced with respect to existing wells and springs, it is estimated that a total of 4,000 to 5,000 hectaremeters of water a year could be withdrawn from the ground-water body in the lowland area of the plain without bringing about overdevelopment and a serious lowering of water levels. 
